\title{
COMPARING EARLY WARNING SYSTEMS FOR BANKING CRISES
}

\author{
E Philip Davis and Dilruba Karim \\ Brunel University and NIESR \\ West London
}

\begin{abstract}
Despite the extensive literature on prediction of banking crises by Early Warning Systems (EWS), their practical use by policy makers is limited, even in the international financial institutions. This is a paradox since the changing nature of banking risks as more economies liberalise and develop their financial systems, as well as ongoing innovation, makes the use of EWS for crisis prevention more necessary than ever. In this context, we assess the logit and signal extraction EWS for banking crises on a comprehensive common dataset. We suggest that logit is the most appropriate approach for global EWS and signal extraction for country specific EWS. Furthermore it is important to consider the policy maker's objectives when designing predictive models and setting related thresholds since there is a sharp trade-off between correctly calling crises and false alarms.
\end{abstract}

Keywords: Banking crises, systemic risk, early warning systems, logit estimation, signal extraction

JEL Classification: C52, E58, G21

\footnotetext{
${ }^{1}$ Davis is Professor of Economics and Finance and Karim is a Doctoral Research Student, Department of Economics and Finance, School of Social Sciences, Brunel University, Uxbridge, Middlesex, UB8 3PH, UK, emails e_philip_davis@msn.com and dilly.karim@gmail.com. Davis is also Visiting Fellow, NIESR, Dean Trench Street, Smith Square, London SW1.
} 


\section{Introduction}

Historic episodes of financial crises highlight the need for Early Warning Systems (EWS) for banking crisis prediction; over 1980-1996, three-quarters of IMF countries experienced banking distress (Lindgren, Garcia and Saal, 1996). Crises were not restricted to particular geographic regions, levels of development or banking system structures ${ }^{2}$. A working definition of a banking crisis is the "occurrence of severely impaired ability of banks to perform their intermediary role". Restriction to a few banks constitutes a localised crisis whereas collapse of the banking system constitutes a systemic crisis.

Systemic crises have significant direct and indirect costs. According to Caprio and Klingebiel (1996), bailout costs average 10\% of GDP, with some crises much more costly, e.g. the Mexican Tequila Crisis (1994) cost 20\% of GDP whilst the Jamaican crisis (1996) cost 37\% of GDP. There are additional costs of foregone economic output (notably reduced investment and consumption) owing inter alia to credit rationing and uncertainty. Hoggarth and Sapporta (2001) estimate that cumulative output losses from banking and twin crises ${ }^{3}$ were much greater in OECD countries $(23.8 \%$ of GDP) than in emerging market economies $(13.9 \%)$. Banking crises alone cost an average of $5.6 \%$ of GDP and twin crises $29.9 \%$.

The IMF uses an early warning system (EWS) to monitor currency crises but has no explicit EWS for banking crises. Likewise, private sector institutions focus on currency crisis prediction. This may partly reflect the historically high prevalence of currency crises; in a study of 20 countries, Kaminsky and Reinhart (1999) found that during the 1970s there were 26 currency crises and only 3 banking crises (due to financial repression). However, banking crises quadrupled in the post-liberalisation period of the 1980s and 1990s. Further increases are foreseeable as additional emerging market countries undergo financial liberalisation, while in more advanced economies, securitised financial markets develop new financially engineered products whose behaviour during recessions is not well understood. For example, Chan et al (2006) note the close relationship between banks and hedge funds which undertake unregulated investments. Related risks are not well understood, but as the LTCM crisis in

\footnotetext{
${ }^{2}$ Caprio and Klingebiel (1996).

${ }^{3}$ Defined as cases where a currency crisis occurs within the period 2 years before and after the banking crisis. Whereas one might anticipate that a currency crisis would mitigate the impact of the banking crisis by increasing the profitability of export and import-competing firms, it seems that this is more than offset by a greater level of financial disruption in a twin crisis, in many cases including a cut-off of international credit, that may aggravate the banking crisis (Kaminsky and Reinhart 1999).
} 
1998 demonstrated ${ }^{4}$, hedge funds with highly leveraged positions can rapidly magnify domestic and international systemic risks, thereby increasing chances of contagion. Hence the need to devise a reliable EWS for banking crisis prevention remains more pressing than ever.

Although models have been developed to allow banking crisis prediction, their comparative performance is difficult to evaluate. Current models have been derived from various historic datasets and more importantly, by using different dependent variables and overall methodologies. Consequently, leading indicators may appear inconsistent and in-sample and out-of-sample results differ. This paper attempts to resolve some of the current ambiguity on predictive efficiency and indicator robustness. Our contribution includes the following: We test two of the main EWS in the literature (multivariate logit and signal extraction) using a single panel dataset. The cross-country and time-series coverage is more extensive than most previous studies. We also consider refinements to current EWS by considering how banking crisis theory could help to improve specification and variable choice. In the specific case of signal extraction work we also distinguish country specific from general effects and construct composite indicators.

In sum, our results show (1) that given the same underlying data, the choice of EWS does make a difference to predictive efficiency. (2) Given the EWS model, the choice of dependent variable determines predictive capacity. (3) Transforming indicators including standardisation, lags and interaction terms improves the performance of the EWS. (4) Some models are better for developing country-specific EWS whilst others are suited to global EWS. (5) Combining variables into composite indicators improves crisis predictive ability. The remainder of the article proceeds as follows: Section I provides a brief theoretical review of banking crises which motivates the choice of indicators. Section II explains the methodology we adopt, including the theory behind the logit and signal extraction methods, construction of the banking crisis dependent variable and our dataset. Section III presents our results, whilst section IV concludes.

\section{Theoretical overview of banking crises.}

This section briefly indicates why the indicators used in EWS models such as Demirguc-Kunt and Detragiache (1998) (who use the logit method) are associated with banking crises. ${ }^{5}$ This enables us to assess the variables' validity and also to recommend extensions.

\footnotetext{
${ }^{4}$ Davis (1999)
} 
Generally, banking systemic risk reflects a correlation of performance between institutions. One possibility is that such crises can be purely self fulfilling, i.e. they materialise through individual liquidity failures of solvent banks that become contagious. In these cases, crises can be driven by asymmetric information and associated bank runs. Diamond and Dybvig (1983) emphasised the role of confidence in precipitating runs and that arbitrary shifts in investors' risk expectations explain seemingly irrational behaviour of consumers running on banks; a bank's underlying financial position is almost irrelevant once panic ensues. Hence individual bank failure may spread through contagion associated with asymmetric information and in this context systemic banking crises are self-fulfilling. This view has been criticised on the view that there is usually a fundamental explanation for such events.

George (1998) suggests that systemic risks arise "through the direct financial exposures" which tie firms together". If systemic risk is sufficiently deep, (i.e. if correlations between individual bank risks are particularly high), then crises could be triggered. Hence a further possibility is that there could be counterparty claims between banks (e.g. via interbank exposures) that lead to widespread failures.

EWS to date have typically ignored the possibility of pure self-fulfilling crises and crises caused simply by counterparty exposures. This can be justified because historically the vast majority of banking crises have been caused by financial institutions underestimating their common exposure to economy wide systematic risk (Borio, Furfine and Lowe, 2001). This may link to asymmetric information as if one significant bank fails, a systemic crisis may develop because the presence of such asymmetric information means depositors are unable to evaluate prospects for "similar" banks in terms of balance-sheet exposure to economy wide systemic risks (Kaufman and Scott, 2003).

Accordingly, macroeconomic movements that crystallise risks particular to banking systems, namely interest rate, credit, liquidity and market risk have been the key determinants of banking crises in the last twenty years (Ergungor and Thompson, 2005). Correspondingly, in most EWS studies, the explanatory variables used mainly capture macroeconomic factors that could generate systemic risk via such common shocks.

\footnotetext{
${ }^{5}$ We note that Kaminsky and Reinhart (1999) (who use the signal extraction method) use a different set of variables more closely associated with currency crisis prediction.

${ }^{6}$ Exposures include inter-bank transactions, counterparty risk, or third party (non-bank institutional) failure.
} 
Interest rate risk forms an inherent part of banking activities since assets have longer duration than liabilities. Term structure shifts towards short-term liabilities (inverted yield curves) adversely affect bank balance sheets by eroding bank spreads. Simultaneously, banks may suffer prepayment risk if long-term rates decline and borrowers refinance at lower rates. These outcomes adversely affect bank balance sheets and if there is significant exposure to interest rate risk, net worth of the banking system becomes vulnerable.

Oviedo (2004) highlights the counter-cyclicality of interest rates; lower interest rates are associated with economic booms when crises are less likely. Consequently, during booms, banks may use low-cost deposit financing to invest heavily in particular sectors which appear profitable and where collateral values are high. This increased appetite for long-term projects means duration mismatch and interest rate risk are likely to accumulate during the boom phase so that unexpected interest rate increases or moves towards inflation targeting in the downturn could lead systemic interest rate risk to materialise. Hence the inclusion of real interest rates in EWS and the observed, positive correlation between real interest rates and banking crisis probability in recent work (Demirguc-Kunt and Detragiache, 1998; Hardy and Pazarbasioglu, 1998; Kaminsky and Reinhart, 1999; Gourinchas, Valdes and Landerretche, 2001).

Another symptom of banking crises is increased credit risk or the probability that a borrower will default, converting an asset into a "bad" or non-performing loan (NPL). Although banks enjoy advantages in screening and monitoring borrowers, both of which reduce credit risk, the high levels of NPLs associated with crises indicate risk assessment by banks deteriorates during pre-crisis periods.

One reason for and consequence of inadequate credit risk evaluation is the procyclical movement of lending and asset prices which allows for interaction of financial cycles and business cycles. Periods of high output growth raise collateral values and as a result, during booms loan contracts become less informationally dependent. Asymmetric information does not restrict credit availability because bank managers succumb to "euphoric" and "herding" behaviour, utilising biased information sets to make investment decisions. As a result, they ignore the potentially high default probabilities that could occur under recessionary states and under-price credit risk. Borio, Furfine and Lowe (2001) attribute these sub-optimal behavioural responses to difficulties in measuring time series of credit risk and to incentive

\footnotetext{
${ }^{7}$ Davis (1995).
} 
based managerial contracts which reward loan volume. As lending increases, this further inflates asset prices, which raises collateral values and perpetuates the endogenous cycle (Davis and Zhu 2004). The boom phase ends when shocks, such as asset price collapses, turn the process backwards; during recessions managers may overestimate risk so that cyclical downturns reverse the financial accelerator. As assets markets collapse, collateral values decline and NPLs rise. Because asymmetric information becomes disproportionately important for loan officers, lending spreads are artificially high and intermediaries hold excess capital and provisions. Ultimately, credit rationing prevents borrowers with profitable projects from obtaining funds and the recession deepens.

Credit risk may be particularly high and correlated between institutions when herding focuses boom-phase investment to specific sectors of the economy. Over-investment in real estate (particularly commercial) has been a well-documented feature of banking crises ${ }^{\mathrm{Q}}$ because the value of bank capital increases if real estate forms the asset base. Bank lending therefore magnifies the real estate cycle, leading to further financial acceleration and financial instability (Herring and Wachter, 1998; Borio, Furfine and Lowe, 2001, Davis and Zhu 2004, 2005). Furthermore credit risk may be magnified by regulation that limits diversification.

In the context of banking crises, market risk is intertwined with credit risk. Market risk reflects the probability that price-volatility of specific assets affects the net worth of banks. Such adverse price movements may arise through shifts in market expectations in anticipation of cyclical downturns. Alternatively, specific asset groups may be hit by idiosyncratic factors, e.g. oil price volatility following political events. Although market risk is diversifiable, regulation limiting types of assets held may impede this. Alternatively, excessive market risk may be borne during boom phases, as over-optimism may concentrate portfolios in assets whose prices move procyclically, e.g. real estate (Gonzalez-Hermosillo, 1999, Craig et al 2005). Since credit risk is also procyclical, the link between the two risks becomes apparent when asset price collapses realise market risk and low collateral values realise credit risk. Banks may also be exposed to market risk if their portfolios are concentrated on equities and currencies; if they fail to adequately provision against price volatility, then adverse price shocks can jeopardise the net worth of the banking system.

\footnotetext{
${ }^{8}$ See FDIC (1997) for the relationship between commercial real estate and US banking crises during the 1980s and 1990s.

${ }^{9}$ The Texan Banking crisis was driven by regulation which forced regional banks and S\&Ls to invest within their state. Texan institutions over-invested in the Texan oil industry which entered recession in 1987 (FDIC, 1997).
} 
Banking liquidity risk reflects the probability that banks will be unable to satisfy the claims of depositors because the ratio of illiquid assets relative to liquid liabilities is too high. In the Diamond and Dybvig (1983) model, liquidity risk drives idiosyncratic bank runs. Liquidity risk also links to adverse information models of banking crises (Santos, 2000). Chari and Jagannathan (1988) modify the Diamond and Dybvig model to show that when depositors assimilate adverse information (e.g. signals of recession or asset market collapses) they anticipate that bank profitability will suffer. Resulting bank runs generate systemic liquidity problems. These runs are distinct from the Diamond and Dybvig model where runs on solvent banks occur even when depositors have no legitimate evidence to suspect insolvency. Rather, in this case, depositors are more likely to run on genuinely insolvent banks. Hence Gorton's (1988) observation that panics are associated with recessions and Jacklin and Bhattacharya's (1988) suggestion that the release of information indicating low asset values or poor performance of a bank can generate liquidity risk.

Financial liberalisation provides another source of the systemic risks mentioned, hence the well-documented association between liberalisation and crises; in the Kaminsky and Reinhart (1999) sample, over $70 \%$ of banking crises were preceded by financial liberalisation within the last five years and the probability of banking crisis conditional on financial liberalisation having occurred is higher than the unconditional probability of banking crisis. Demirguc-Kunt and Detragiache (1998) also find financial liberalisation increases crisis risk within a few years of the liberalisation process.

High real interest rates and increased interest rate volatility are typical consequences of financial liberalisation, especially in developing countries (Honohan, 2000). During financial repression, imposed ceilings mean real interest rates cannot adjust to clear credit markets and credit rationing results in "non-market", usually state-directed, credit allocation. Although interest rate risk considerations are likely to be subordinate when states allocate credit, interest rate ceilings have some risk limiting effect. However in post-liberalised environments, wider spreads and increased competition could cause an accumulation of systemic interest rate risk which may be more likely to materialise because of higher interest rate volatility.

Another effect of financial liberalisation may be to increase credit risk. In liberalised markets, increased competition may erode bank charter values so that without adequate supervision and regulation, banks forgo prudent credit risk assessment in a bid to catch borrowers. Hence financial liberalisation can exaggerate procyclicality of asset prices by fuelling a consumption 
boom (Borio, Furfine and Lowe (2002)). Craig et al (2005) suggest that credit risk increases following liberalisation because the rapid increases in loan volumes constrain credit risk assessment. This may be exacerbated in the presence of government safety nets; DemirgucKunt and Detragiache (1998) show deposit insurance is a significant leading indicator of banking crisis and the same authors (2002) show explicit deposit insurance increases the risk of moral hazard when institutions are weak. Where financial liberalisation does increase asset price volatility, there may also be increased liquidity risk borne by the system since banks are unable to sell assets at par when asset prices collapse.

Looking at the indicators typically used in EWS models, in the light of the discussion above, we would thus expect rapid real credit growth and increases in private sector credit/ GDP during pre-crisis periods, indicating credit risk accumulation. Similarly procyclicality of financial instability implies GDP growth should capture boom and bust cycles. Liquidity risk is incorporated by bank cash plus reserves as a proportion of total bank assets; the lower this ratio the higher the systemic liquidity risk. Macroeconomic shocks which could trigger cyclical downturns thereby increasing NPLs include adverse movements in terms of trade and correspondingly currency depreciations, especially for small open economies. The latter also indicates vulnerability to currency crisis, as does M2/ foreign exchange reserves since lower ratios imply impaired ability to defend the currency. Real interest rates are used as a direct indicator of interest rate risk. High inflation signals policy mismanagement which causes higher nominal interest rates at the expense of lenders. Corresponding increases in interest rate volatility should also capture interest rate risk. Higher inflation may also, to a certain extent, reflect market risk of asset price booms. Direct use of asset prices such as real estate for proxying market risk in EWS models has been limited due to lack of data outside the OECD countries. On the other hand exchange rate based market risk is proxied by the terms of trade and currency depreciations.

Policy mismanagement is also reflected in low fiscal surpluses/ GDP. Demirguc-Kunt and Detragiache (1998) include this variable because it indicates governments' reluctance to restructure fragile banking systems and because high deficits prevent successful financial liberalisation. Real interest rates also act as a proxy for financial liberalisation. Furthermore, Demirguc-Kunt and Detragiache rely on the level of GDP per capita as a structural economic development measure which should be positively related to the quality of banking

\footnotetext{
${ }^{10}$ However, the level of the credit/GDP ratio is rather an indicator of economic and financial development.
} 
regulation ${ }^{11}$. Given these leading indicators, we now turn to describe the construction of the banking crisis dependent variable and the actual models used to predict banking crises.

\section{Data, variables and specifications}

\subsection{The Banking Crisis Variable}

The most commonly-cited problem with EWS developed to date is the inconsistency in the banking crisis dependent variable, which is necessarily defined with a degree of subjectivity (Kaminsky and Reinhart, 1999; Demirguc-Kunt and Detragiache 1998, Eichengreen and Arteta, 2000). There is no unique quantitative variable for banking crisis. The problem lies in the fact that banking crisis is an event, so proxies for banking crises would not necessarily be perfectly correlated with banking crises themselves. For instance, if we were to use a measure for banking insolvency such as aggregate banking capital, we would need to define a lower bound threshold for a crisis event. However, government intervention or deposit insurance could prevent crisis and the threshold could still be violated. Another issue is that not all crises stem from the liabilities side (Kaminsky and Reinhart, 1999); problems in asset quality can also erode banking capital so that a single proxy variable would not pick up all crisis events. As a result the dummy is constructed on the basis of several criteria which vary according to the study. The main classifications are to be found in Caprio and Klingebiel (1996, 2003), Demirguc-Kunt and Detragiache (1998, 2005), Kaminsky and Reinhart (1999) and Lindgren, Garcia and Saal (1996).

Caprio and Klingebiel (1996) focus on the solvency side of crisis and define systemic crisis as an event when "all or most of banking capital is exhausted" basis of official data and published reports by financial market experts; if official data recorded positive banking system capital but experts judged it to be negative, they recorded systemic crisis 13 . Caprio and Klingebiel (2003) subsequently updated their database to the period 1980-2002 and identified 93 countries as having experienced systemic crises.

\footnotetext{
${ }^{11}$ Demirguc-Kunt and Detragiache (1998) also incorporate two other institutional variables: a deposit insurance dummy (where explicit deposit insurance means the dummy value is 1) and a law and order dummy.

${ }^{12}$ They stipulate that non-performing loans as a proportion of entire loans of the banking system must be in the range of $5-10 \%$ or less.

${ }^{13}$ On this criterion, they judged 58 countries to have experienced systemic crisis over the post-1970s period with many experiencing repeated episodes.
} 
Demirguc-Kunt and Detragiache (1998) used a more specific set of four criteria ${ }^{14}$ where achievement of at least one of the conditions was a requirement for systemic crisis, otherwise bank failure was non-systemic. The authors admitted they relied on judgement if there was insufficient evidence to support their crisis criteria; on this basis they established 31 systemic crises in 65 countries over the 1980-1994 period. Demirguc-Kunt and Detragiache (2005) conducted a follow up study and extended the sample to 1980-2002. Using the same criteria as before, they find 77 systemic crises over 94 countries.

Kaminsky and Reinhart (1999) and Lindgren, Garcia and Saal (1996) use criteria similar to Demirguc-Kunt and Detragiache (1998). Kaminsky and Reinhart (1999) identified 26 systemic banking crises over 20 countries during the period 1970-1995. Of the 26 crises, 19 are twinned with currency crises and the remaining 7 are pure banking crises.

Even if systemic crises unambiguously occur, identifying their starting and ending dates is hazardous and the same episode may have a different duration in different studies. Where runs do not occur and banking system data are either unavailable or unreliable, locating the exact time when the system became insolvent is impossible. Even if runs do occur, this may be a culmination of a prolonged period of systemic insolvency, which was either unknown to depositors or supported by government assistance at and earlier stage. Based on the run, the start date would "time" the crisis too late.

Kaminsky and Reinhart (1999) note that crises can also be dated too early, since the worst of the crisis could unfold after the subjective start date. Dating is also problematic when there are successions of crises episodes; in many such instances it is arguable that later crises are extensions or re-emergences of previous financial distress as opposed to distinct crises events (Caprio and Klingebiel, 1996). Judgment is also required to distinguish between periods of systemic and non-systemic crisis; a degree of banking system insolvency must be decided upon whereby failure of a few banks is recorded as a localised crisis and beyond this crisis becomes systemic. Not all studies make this distinction in the same way so that a crisis may

\footnotetext{
${ }^{14}$ The proportion of non-performing loans to total banking system assets exceeded $10 \%$, or the public bailout cost exceeded $2 \%$ of GDP, or systemic crisis caused large scale bank nationalisation, or extensive bank runs were visible and if not, emergency government intervention was visible.

15 For Kaminsky and Reinhart (1999), a crisis is systemic if banks runs result in closure or nationalisation of at least one bank, or if there are no runs, large-scale government intervention, merging or nationalisation of one bank marks the beginning of the same for other banks. Lindgren, Garcia and Saal (1996) classify systemic crises on the basis of whether bank runs, portfolio shifts, bank collapses or large-scale government intervention occur. Any other episodes of financial instability are classed as non-systemic crises.
} 
be a systemic event in one paper but remain excluded from the banking crisis dummy in another.

Whichever crisis definition is used, the crisis duration must be handled carefully in order to avoid endogeneity; once a crisis occurs it is likely to deepen any recession and affect the explanatory variables. Studies have addressed this feedback in various ways: Demirguc-Kunt and Detragiache (1998) conduct two sets of regressions, one by discarding all observations after a crisis begins and another by discarding observations after a crisis has ended $\frac{16}{6}$. Others have arbitrarily assumed a common duration for all crises, e.g. 18 months (Kaminsky and Reinhart, 1999) or 1 year (Eichengreen and Arteta, 2000; Glick and Hutchinson, 1999).

The subjectivity associated with banking crisis identification may explain why almost all authors have relied on the studies mentioned above, either wholly or in combination, to construct their banking crisis variable. The disadvantage of this is that all research has focused on a few assessments of crisis occurrence. The advantage is that it reduces multiplicity in the dependent variable amongst studies. In this vein, we will also rely on the Demirguc-Kunt and Detragiache (2005) and Caprio and Klingebiel (2003) crises lists. Henceforth we refer to the Demirguc-Kunt and Detragiache (2005) dates/ dummy as DD05 and the Caprio and Klingebiel (2003) dates/ dummy as CK03.

\subsection{The Data Sample}

The dataset of independent variables mimics the Demirguc-Kunt and Detragiache (1998) approach, utilising most of their variables but for a wider selection of countries and for a longer time span. We have used the same data source they cite: IFS and World Bank Development Indicators to obtain annual data; full data sources are obtainable in DemirgucKunt and Detragiache (1998). A maximum of 105 countries are included whilst the data spans the period 1979 to 2003. Under the DD05 dating this yields 72 systemic crisis episodes; under the less stringent CK03 definitions this yields 102 systemic crisis episodes. Almost half the countries included in our full sample experienced no systemic crisis based on DD05 dates, whereas under a fifth were non-crisis countries based on the CK03 dates.

As explained in Part 1, the explanatory variables chosen are macroeconomic, financial and financial liberalisation indicators of crisis. Table 1 below gives the indicator list.

\footnotetext{
${ }^{16}$ They find the results do not change significantly either way.
} 
Table 1: The Demirguc-Kunt and Detragiache (1998) Variables

\begin{tabular}{|c|l|}
\hline \multirow{4}{*}{ Macroeconomic Variables } & 1. Real GDP Growth (\%) \\
\cline { 2 - 2 } & 2. Change in Terms of Trade (\%) \\
\cline { 2 - 2 } & 3. Nominal Depreciation (\%) \\
\cline { 2 - 2 } & 4. Real Interest Rate (\%) \\
\cline { 2 - 2 } & 5. Inflation (\%) \\
\cline { 2 - 2 } & 6. Fiscal Surplus/ GDP (\%) \\
\hline \multirow{4}{*}{ Financial Variables } & 7. M2/ Foreign Exchange Reserves (\%) \\
\cline { 2 - 2 } & 8. Credit to Private Sector/ GDP (\%) \\
\cline { 2 - 2 } & 9. Bank Liquid Reserves/ Total Bank Assets (\%) \\
\cline { 2 - 2 } Institutional Variables & 10. Real Domestic Credit Growth (\%) \\
\hline & 11. Real GDP per Capita \\
\cline { 2 - 2 } & 12. Deposit Insurance (binary dummy) \\
\hline
\end{tabular}

\subsection{The Demirguc-Kunt and Detragiache (1998) Mulivariate Logit Model}

The multivariate logit approach allowed Demirguc-Kunt and Detragiache (1998) to relate the likelihood of occurrence or non-occurrence of a banking crisis to a vector of $n$ explanatory variables. The probability that the banking dummy takes a value of one (crisis occurs) at a point in time is given by the value of the logistic cumulative distribution evaluated for the data and parameters at that point in time. Thus,

$\operatorname{Prob}\left(Y_{i t}=1\right)=F\left(\beta X_{i t}\right)=\frac{e^{\beta^{\prime} X_{i t}}}{1+\mathrm{e}^{\beta^{\prime} X_{i t}}}$

where $Y_{i t}$ is the banking crisis dummy for country $i$ at time $t, \beta$ is the vector of coefficients, $\mathrm{X}_{\mathrm{it}}$ is the vector of explanatory variables and $\mathrm{F}\left(\beta \mathrm{X}_{\mathrm{it}}\right)$ is the cumulative logistic distribution. The parameters are obtained by maximum likelihood estimation where each possible value of $\mathrm{Y}_{\text {it }}$ contributes to the joint likelihood function so that the log likelihood becomes

$\log _{e} L=\sum_{i=1}^{n} \sum_{t=1}^{T}\left[\left(Y_{i t} \log _{e} F\left(\beta^{\prime} X_{i t}\right)\right)+\left(1-Y_{i t}\right) \log _{e}\left(1-F\left(\beta^{\prime} X_{i t}\right)\right)\right]$

The parameters obtained by maximising this function are not constant marginal effects of $\mathrm{X}_{\mathrm{i}}$ on the crisis probability since the underlying relationship is non-linear. Rather, the marginal effect of $\mathrm{X}_{\mathrm{it}}$ on $\mathrm{Y}_{\mathrm{it}}$ is given by the probability of crisis times the probability of no crisis times 
the coefficient $\beta_{i}^{17}$. Since the probabilities depend on the values of $\mathrm{X}_{\mathrm{it}}$, for a given coefficient, a single explanatory variable can have changing marginal contributions to crisis probability depending on its starting level. The sigmoidal logistic cumulative distribution shows that an explanatory variable will make marginally little difference to crisis if the crisis probability is already at the extreme (low or high) but if crisis probability is around the 0.5 range then a change in the same variable is more likely to tip the balance and trigger crisis $\frac{18}{11}$. The sign on the coefficient still indicates the direction of change on crisis probability. To directly compare the individual contributions of each variable to crisis, their marginal effects can be computed for their mean values (Greene, 2000) or at a specific year before a crisis unfolds.

Demirguc-Kunt and Detragiache (1998) do not use a fixed effects logit model; a fixed effects model would mean the country specific dummy and the banking crisis dummy would be perfectly correlated for countries which never experienced a banking crisis. Excluding these countries would generate a biased sample and biased coefficients. Rather, they use a sample composed of crisis and non-crisis countries where the latter represent controls. In this way, variation in the explanatory variables is fully used to explain why crisis will or will not occur.

The advantage of this parametric approach is that it takes into account the interdependencies of explanatory variables which in combination could trigger crisis. In this sense, the model corresponds to much of the theory outlined in Part 1 where concurrent increases in real interest rates, GDP and credit growth in the presence of financial liberalisation seem to predispose economies to crisis.

\subsection{The Kaminsky and Reinhart (1999) Signal Extraction Model}

This is a non-parametric approach which assesses the behaviour of single variables prior to and during crisis episodes. The logic is that if aberrant behaviour of a variable can be quantitatively defined then whenever that variable moves from tranquil to abnormal activity, crisis is forewarned. Let

$\mathrm{i}=\mathrm{a}$ univariate indicator

\footnotetext{
${ }^{17}$ The probit model is also equally valid for the banking crisis context; in this case the normal distribution underlies the likelihood function and the marginal effects are given by the variable's contribution to crisis. probability times the coefficient. Multivariate probit has been used by Eichengreen and Rose (1998) and Glick and Hutchison (1999) amongst others.

${ }^{18}$ Conversely, an improvement in the variable could cause a significant marginal reduction in crisis probability.
} 
$\mathrm{j}=$ a particular country

$\mathrm{S}=$ signal variable

$\mathrm{X}=$ indicator

An indicator variable relating to indicator $i$ and country $j$ is denoted by $X_{i}^{j}$ and the threshold for this indicator is denoted as $\mathrm{X}^{*}{ }_{\mathrm{i}}^{\mathrm{j}} \mathrm{A}$ signal variable relating to indicator $\mathrm{i}$ and country $\mathrm{j}$ is denoted by: $S_{i}{ }_{i}^{j}$. This is constructed to be a binary variable where $S_{i}{ }^{j}=\{0,1\}$. If the variable crosses the threshold, a signal is emitted and $\mathrm{S}_{\mathrm{i}}{ }^{\mathrm{j}}=1$. This happens when

$$
\left\{\mathrm{S}_{\mathrm{i}}^{\mathrm{j}}=1\right\}=\left\{\left|\mathrm{X}_{\mathrm{i}}^{\mathrm{j}}\right|>\left|\mathrm{X}_{\mathrm{i}}^{* \mathrm{j}}\right|\right\}
$$

If the indicator remains within its threshold boundary, it behaves normally and does not issue a signal so $\mathrm{S}_{\mathrm{i}}^{\mathrm{j}}=0$,

$$
\left\{\mathrm{S}_{\mathrm{i}}^{\mathrm{j}}=0\right\}=\left\{\left|\mathrm{X}_{\mathrm{i}}^{\mathrm{j}}\right|<\left|\mathrm{X}^{*}{ }_{\mathrm{i}}^{\mathrm{j}}\right|\right\}
$$

Hence in a global EWS, panel data is used to derive a threshold for each variable, which distinguishes between normal and aberrant behaviour. Notice the directional sign may vary depending on whether the indicator in question has an upper or lower bound; hence the variables and thresholds in equations (3) and (4) are expressed in absolute terms. Thus for a time series of $t$ observations for country $j$ and indicator $i$ we can obtain a binary time series of signal or no-signal observations. This series is then checked against actual events to construct

\begin{tabular}{|c|c|c|}
\hline & CRISIS & NO CRISIS \\
\hline$\underset{⿱ 乛}{Z}$ & $\mathrm{~A}$ & B \\
\hline 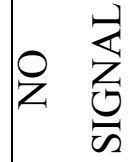 & $\mathrm{C}$ & $\mathrm{D}$ \\
\hline
\end{tabular}
a measure of predictive accuracy. There are four possible scenarios:

If the indicator signals crisis and this correlates with an actual crisis, the outcome is denoted ' $A$ '. If the signal is not matched by a crisis in reality, the outcome is denoted ' $B$ '. If no signal is emitted by the indicator but there was an actual crisis, the outcome is called ' $\mathrm{C}$ '. If no signal is emitted and there really is no crisis, the outcome is ' $D$ '. 
Hence a perfect indicator would produce outcomes A and D only; it would correctly call all crises and would not issue signals unnecessarily. Outcome $\mathrm{C}$ represents a failure to call crisis (Type I error) and outcome B generates a false alarm (Type II error). Hence a measure of signalling accuracy can be constructed for each indicator, based on the proportion of false alarms and missed crises; there are various criteria (e.g. minimise Type I error only) so the chosen measure will reflect the desires of the policy maker or private institution using the EWS. This is based on the inherent trade-off between Type I and Type II errors which are functions of the threshold; changing the threshold to allow more crises to be picked up necessarily raises the likelihood of false alarms. A policy maker concerned with avoiding crises at all costs may choose to minimise Type I errors even if this entails unnecessary intervention (or at least, investigation) due to more Type II errors. Likewise, in currency crisis models, private sector investors with positions entailing a large amount of exchange rate risk may prefer wider thresholds giving them time to take alternative investment positions. On the other hand, policy makers with relatively stable financial systems may prefer avoiding Type II errors and undue intervention.

Kaminsky and Reinhart (1999) choose to minimise the probability of failing to call crisis and the probability of false alarms simultaneously. Specifically, the Noise to Signal Ratio (henceforth NTSR) is given by (Type II error/ 1 - Type I error). As with normal hypothesis testing, changing the threshold to reduce Type I errors necessarily increases the number of Type II errors. The NTSR measure takes this trade-off into account; the optimal threshold will minimise the numerator and maximise the denominator of the NTSR. Different percentiles of the entire panel (i.e. cross-country) series are taken as thresholds and the corresponding NTSR is evaluated. The percentile that minimises the NTSR is selected and applied to each country to produce a country specific threshold which forms the benchmark for the EWS. The advantage of this non-parametric approach is that it focuses on a particular variable's association with crisis and that it can be based on high frequency data.

\section{$3 \quad$ Results}

\subsection{Replication of Demirguc Kunt and Detragiache (2005)(denoted DD05)}

Following the DD05 procedure, regressions were conducted with three sets of explanatory variables: macroeconomic only (minus fiscal), macroeconomic (minus fiscal) with financial, 
macroeconomic with financial and institutional. Tables 2-5 show our results against the benchmark DD05 results. We also report the models' Akaike's Information Criterion and the Wald test statistic which tests the null that all coefficients equal zero.

Table 2: Regression 1: Macroeconomic (minus fiscal) Variables Only

\begin{tabular}{|c|c|c|c|}
\hline & Original & \multicolumn{2}{|c|}{ Replication } \\
\hline & D\&D (2005) Paper & $\begin{array}{c}\mathrm{D} \& \mathrm{D}(2005) \text { crisis } \\
\text { dummy }\end{array}$ & $\begin{array}{l}\text { C\&K (2003) } \\
\text { crisis dummy }\end{array}$ \\
\hline & $\begin{array}{l}(1980-2002) \\
94 \text { countries, } \\
77 \text { crisis } \\
\text { occurrences }\left(1^{\text {st }}\right. \\
\text { crisis year only) }\end{array}$ & $\begin{array}{c}(1979-2003) \\
105 \text { countries, } 72 \\
\text { crisis } \\
\text { occurrences }\left(1^{\text {st }}\right. \\
\text { crisis year only) }\end{array}$ & $\begin{array}{c}(1979-2003) \\
105 \text { countries, } \\
121 \text { crisis occurrences } \\
\left(1^{\text {st }} \text { crisis year only) }\right.\end{array}$ \\
\hline Real GDP Growth & $\begin{array}{c}-0.0967^{* * * *} \\
(0.0259)\end{array}$ & $\begin{array}{c}-0.1693^{* * *} \\
(0.0332)\end{array}$ & $\begin{array}{c}-0.1177^{* * * *} \\
(0.0240)\end{array}$ \\
\hline Change in Terms of Trade & $\begin{array}{c}0.0005 \\
(0.0061)\end{array}$ & $\begin{array}{c}-0.0285^{* * *} \\
(0.0023)\end{array}$ & $\begin{array}{c}-0.0191^{* * * *} \\
(0.0016)\end{array}$ \\
\hline Depreciation & $\begin{array}{l}-0.0675 \\
(0.3892)\end{array}$ & $\begin{array}{c}0.0000 \\
(0.0011)\end{array}$ & $\begin{array}{c}0.0000 \\
(0.0003)\end{array}$ \\
\hline Real Interest Rate & $\begin{array}{l}0.0006^{* * *} \\
(0.0002)\end{array}$ & $\begin{array}{l}0.0243^{* *} \\
(0.0108)\end{array}$ & $\begin{array}{l}0.0416^{*} \\
(0.0242)\end{array}$ \\
\hline Inflation & $\begin{array}{l}0.0007^{* *} \\
(0.0003)\end{array}$ & $\begin{array}{l}-0.0012 \\
(0.0000)\end{array}$ & $\begin{array}{c}0.0010 \\
(0.0006)\end{array}$ \\
\hline Real GDP per Capita $^{\dagger}$ & $\begin{array}{l}-0.0367^{*} \\
(0.0156)\end{array}$ & $\begin{array}{l}-0.0347^{*} \\
(0.0196)\end{array}$ & $\begin{array}{c}-0.0391^{* * *} \\
(0.0139)\end{array}$ \\
\hline Fiscal Balance/ GDP & $X$ & $\mathrm{X}$ & $\mathrm{X}$ \\
\hline M2/ International Reserves & $X$ & $\mathrm{X}$ & $\mathrm{X}$ \\
\hline Private Credit/ GDP & $X$ & $\mathrm{X}$ & $\mathrm{X}$ \\
\hline Deposit Insurance & $X$ & $\mathrm{X}$ & $\mathrm{X}$ \\
\hline Credit Growth (-2) & $\mathrm{X}$ & $\mathrm{X}$ & $\mathrm{X}$ \\
\hline Wald Test Statistic & & $412.67^{* * *}$ & $264.01^{* * *}$ \\
\hline AIC & 593 & 0.3102 & 0.5084 \\
\hline Observations & 1670 & 1314 & 1491 \\
\hline
\end{tabular}

Note: ${ }^{*}$ significant at $10 \%,{ }^{* *}$ significant at $5 \%,{ }^{* * *}$ significant at $1 \%$, standard errors in parenthesis. ${ }^{\dagger}$ indicates a coefficient has been multiplied by 1,000 to overcome scaling issues. 
Table 3: Regression 2: Macroeconomic (minus fiscal) and Financial Variables

\begin{tabular}{|c|c|c|c|}
\hline & Original & \multicolumn{2}{|c|}{ Replication } \\
\hline & D\&D (2005) Paper & $\begin{array}{c}\text { D\&D (2005) crisis } \\
\text { dummy }\end{array}$ & $\begin{array}{c}\text { C\&K (2003) crisis } \\
\text { dummy }\end{array}$ \\
\hline & $\begin{array}{c}(1980-2002) \\
94 \text { countries, } \\
75 \text { crisis } \\
\text { occurrences } \\
\left(1^{\text {st }} \text { crisis year only) }\right.\end{array}$ & $\begin{array}{l}\text { (1979 - 2003) } \\
105 \text { countries, } 42 \\
\text { crisis occurrences }\left(1^{\text {st }}\right. \\
\text { crisis year only) }\end{array}$ & $\begin{array}{c}(1979-2003) \\
105 \text { countries, } \\
77 \text { crisis occurrences } \\
\left(1^{\text {st }} \text { crisis year only }\right)\end{array}$ \\
\hline Real GDP Growth & $\begin{array}{c}-0.0991^{* * *} \\
(0.0265)\end{array}$ & $\begin{array}{c}-0.1964^{* * *} \\
(0.0362)\end{array}$ & $\begin{array}{c}-0.1368^{* * *} \\
(0.0273)\end{array}$ \\
\hline Change in Terms of Trade & $\begin{array}{c}0.0006 \\
(0.0064)\end{array}$ & $\begin{array}{c}-0.0273^{* * *} \\
(0.0024)\end{array}$ & $\begin{array}{c}-0.0193^{* * *} \\
(0.0018)\end{array}$ \\
\hline Depreciation & $\begin{array}{c}0.0713 \\
(0.3830)\end{array}$ & $\begin{array}{c}0.0000 \\
(0.0001)\end{array}$ & $\begin{array}{c}0.0000 \\
(0.0003)\end{array}$ \\
\hline Real Interest Rate & $\begin{array}{l}0.0005^{* * *} \\
(0.0002)\end{array}$ & $\begin{array}{l}0.0268^{* *} \\
(0.0122)\end{array}$ & $\begin{array}{c}0.0293 \\
(0.0275)\end{array}$ \\
\hline Inflation & $\begin{array}{l}0.0006^{* *} \\
(0.0003)\end{array}$ & $\begin{array}{c}0.0002 \\
(0.0012)\end{array}$ & $\begin{array}{c}0.0009 \\
(0.0007)\end{array}$ \\
\hline Real GDP per Capita & $\begin{array}{c}-0.0359^{* * *} \\
(0.0168)\end{array}$ & $\begin{array}{c}0.0000 \\
(0.1718) \\
\end{array}$ & $\begin{array}{c}0.0000 \\
(0.0000)\end{array}$ \\
\hline Fiscal Balance/ GDP & $\mathrm{X}$ & $\mathrm{X}$ & $\mathrm{X}$ \\
\hline M2/ International Reserves & $\begin{array}{l}0.0012^{*} \\
(0.0007)\end{array}$ & $\begin{array}{c}0.0000 \\
(0.0003)\end{array}$ & $\begin{array}{l}-0.0008 \\
(0.0018)\end{array}$ \\
\hline Private Credit/ GDP & $\begin{array}{l}0.0010^{* * *} \\
(0.0003)\end{array}$ & $\begin{array}{l}-0.0006 \\
(0.0010)\end{array}$ & $\begin{array}{c}0.0000 \\
(0.0001)\end{array}$ \\
\hline Credit Growth (-2) & $\begin{array}{l}0.0038^{* *} \\
(0.0019)\end{array}$ & $\begin{array}{l}-0.0005 \\
(0.0009) \\
\end{array}$ & $\begin{array}{c}0.0005 \\
(0.0010) \\
\end{array}$ \\
\hline Deposit Insurance & $\mathrm{X}$ & $\mathrm{X}$ & $\mathrm{X}$ \\
\hline Wald Test Statistic & & $355.24^{* * *}$ & $365.05^{* * *}$ \\
\hline $\mathrm{AIC}$ & 579 & 0.3200 & 0.5323 \\
\hline Observations & 1612 & 1153 & 1327 \\
\hline
\end{tabular}


Table 4: Regression 3: Macroeconomic, Financial and Fiscal Variables.

\begin{tabular}{|c|c|c|c|}
\hline & Original & \multicolumn{2}{|c|}{ Replication } \\
\hline & D\&D (2005) Paper & $\begin{array}{c}\mathrm{D} \& \mathrm{D}(2005) \text { crisis } \\
\text { dummy }\end{array}$ & $\begin{array}{l}\text { C\&K (2003) } \\
\text { crisis dummy }\end{array}$ \\
\hline & $\begin{array}{c}(1980-2002) \\
94 \text { countries, } \\
65 \text { crisis occurrences } \\
\left(1^{\text {st }} \text { crisis year only) }\right.\end{array}$ & $\begin{array}{c}(1979-2003) \\
105 \text { countries, } 42 \text { crisis } \\
\text { occurrences }\left(1^{\text {st }} \text { crisis year }\right. \\
\text { only) }\end{array}$ & $\begin{array}{c}(1979-2003) \\
105 \text { countries, } \\
70 \text { crisis occurrences } \\
\left(1^{\text {st }} \text { crisis year only }\right)\end{array}$ \\
\hline Real GDP Growth & $\begin{array}{l}-0.1115^{* * *} \\
(0.0319)\end{array}$ & $\begin{array}{l}-0.1891^{* * *} \\
(0.0402)\end{array}$ & $\begin{array}{c}-0.1677^{* * *} \\
(0.0338)\end{array}$ \\
\hline $\begin{array}{c}\text { Change in Terms of } \\
\text { Trade }\end{array}$ & $\begin{array}{l}-0.0024 \\
(0.0066)\end{array}$ & $\begin{array}{c}-0.0288^{* * *} \\
(0.0030)\end{array}$ & $\begin{array}{c}-0.0150^{* * *} \\
(0.0028)\end{array}$ \\
\hline Depreciation & $\begin{array}{l}-0.1037 \\
(0.3918)\end{array}$ & $\begin{array}{c}0.0000 \\
(0.0002)\end{array}$ & $\begin{array}{l}-0.0002 \\
(0.0002)\end{array}$ \\
\hline Real Interest Rate & $\begin{array}{l}0.0005^{* * *} \\
(0.0002)\end{array}$ & $\begin{array}{l}0.0313^{* *} \\
(0.0128)\end{array}$ & $\begin{array}{c}0.0034 \\
(0.0138)\end{array}$ \\
\hline Inflation & $\begin{array}{l}0.0007^{* *} \\
(0.0003)\end{array}$ & $\begin{array}{c}0.0002 \\
(0.0014)\end{array}$ & $\begin{array}{l}-0.0161 \\
(0.0102)\end{array}$ \\
\hline Real GDP per Capita ${ }^{\dagger}$ & $\begin{array}{l}-0.0414^{* *} \\
(0.0175)\end{array}$ & $\begin{array}{l}-0.0275 \\
(0.0215)\end{array}$ & $\begin{array}{l}-0.0303^{* *} \\
(0.0147)\end{array}$ \\
\hline Fiscal Balance/ GDP & $\begin{array}{l}0.0033^{* *} \\
(0.0016)\end{array}$ & $\begin{array}{l}-0.0498 \\
(0.0348)\end{array}$ & $\begin{array}{c}0.0402 \\
(0.0314)\end{array}$ \\
\hline $\begin{array}{l}\text { M2/ International } \\
\text { Reserves }\end{array}$ & $\begin{array}{l}0.0062^{* * *} \\
(0.0021)\end{array}$ & $\begin{array}{c}0.0000 \\
(0.0002)\end{array}$ & $\begin{array}{l}-0.0001 \\
(0.0004)\end{array}$ \\
\hline Private Credit/ GDP & $\begin{array}{l}0.0016^{* * *} \\
(0.0004)\end{array}$ & $\begin{array}{l}-0.0007 \\
(0.0010)\end{array}$ & $\begin{array}{c}0.0000 \\
(0.0001)\end{array}$ \\
\hline Credit Growth (-2) & $\begin{array}{c}0.0044^{*} \\
(0.0023)\end{array}$ & $\begin{array}{l}-0.0004 \\
(0.0010)\end{array}$ & $\begin{array}{l}-0.0117^{* *} \\
(0.0048)\end{array}$ \\
\hline Deposit Insurance & $\mathrm{X}$ & $\mathrm{X}$ & $\mathrm{X}$ \\
\hline Wald Test Statistic & & $293.58^{* * *}$ & $311.31^{* * *}$ \\
\hline $\mathrm{AIC}$ & 494 & 0.3306 & 0.5276 \\
\hline Observations & 1612 & 1153 & 1327 \\
\hline
\end{tabular}


Table 5: Regression 4: All Variables

\begin{tabular}{|c|c|c|c|}
\hline & Original & \multicolumn{2}{|c|}{ Replication } \\
\hline & D\&D (2005) Paper & $\begin{array}{l}\text { D\&D (2005) crisis } \\
\text { dummy }\end{array}$ & $\begin{array}{c}\text { C\&K (2003) crisis } \\
\text { dummy }\end{array}$ \\
\hline & $\begin{array}{c}(1980-2002) \\
94 \text { countries, } \\
77 \text { crisis } \\
\text { occurrences } \\
\left(1^{\text {st }} \text { crisis year only }\right)\end{array}$ & $\begin{array}{c}(1979-2003) \\
105 \text { countries, } 38 \\
\text { crisis occurrences }\left(1^{\text {st }}\right. \\
\text { crisis year only) }\end{array}$ & $\begin{array}{c}(1979-2003) \\
105 \text { countries, } \\
61 \text { crisis occurrences } \\
\left(1^{\text {st }} \text { crisis year only }\right)\end{array}$ \\
\hline Real GDP Growth & $\begin{array}{c}-0.1175^{* * *} \\
(0.0332)\end{array}$ & $\begin{array}{c}-0.1925^{* * *} \\
(0.0405)\end{array}$ & $\begin{array}{c}-0.1706^{* * *} \\
(0.0340)\end{array}$ \\
\hline Change in Terms of Trade & $\begin{array}{l}-0.0028 \\
(0.0067)\end{array}$ & $\begin{array}{c}-0.0302^{* * *} \\
(0.0034)\end{array}$ & $\begin{array}{c}-0.0159^{* * *} \\
(0.0030)\end{array}$ \\
\hline Depreciation & $\begin{array}{l}-0.1233 \\
(0.3946)\end{array}$ & $\begin{array}{c}0.0000 \\
(0.0002)\end{array}$ & $\begin{array}{l}-0.0002 \\
(0.0002)\end{array}$ \\
\hline Real Interest Rate & $\begin{array}{l}0.0006^{* * *} \\
(0.0002)\end{array}$ & $\begin{array}{l}0.0314^{* *} \\
(0.0131)\end{array}$ & $\begin{array}{c}0.0009 \\
(0.0145)\end{array}$ \\
\hline Inflation & $\begin{array}{c}0.0007 \\
(0.0003)\end{array}$ & $\begin{array}{c}0.0003 \\
(0.0013)\end{array}$ & $\begin{array}{l}-0.0172^{*} \\
(0.0105)\end{array}$ \\
\hline Real GDP per Capita $^{\dagger}$ & $\begin{array}{c}-0.0544^{* * *} \\
(0.0184)\end{array}$ & $\begin{array}{l}-0.0318 \\
(0.0220)\end{array}$ & $\begin{array}{c}-0.0349^{* *} \\
(0.0154)\end{array}$ \\
\hline Fiscal Balance/ GDP & $\begin{array}{l}0.0014^{* *} \\
(0.0020)\end{array}$ & $\begin{array}{l}-0.0496 \\
(0.0352)\end{array}$ & $\begin{array}{c}0.0440 \\
(0.0318)\end{array}$ \\
\hline M2/ International Reserves & $\begin{array}{l}0.0066^{* * *} \\
(0.0022)\end{array}$ & $\begin{array}{c}0.0000 \\
(0.0002)\end{array}$ & $\begin{array}{c}-0.0001 \\
(0.0005) \\
\end{array}$ \\
\hline Private Credit/ GDP & $\begin{array}{l}0.0012^{* * *} \\
(0.0005)\end{array}$ & $\begin{array}{l}-0.0008 \\
(0.0011)\end{array}$ & $\begin{array}{l}-0.0001 \\
(0.0001)\end{array}$ \\
\hline Credit Growth (-2) & $\begin{array}{c}0.0041^{*} \\
(0.0022)\end{array}$ & $\begin{array}{l}-0.0005 \\
(0.0011)\end{array}$ & $\begin{array}{c}-0.0120^{* * * *} \\
(0.0049)\end{array}$ \\
\hline Deposit Insurance & $\begin{array}{l}0.5859^{* *} \\
(0.2786)\end{array}$ & $\begin{array}{c}0.3477 \\
(0.3607)\end{array}$ & $\begin{array}{c}0.3549 \\
(0.2942)\end{array}$ \\
\hline Wald Test Statistic & & $291.06^{* * * *}$ & $416.11^{* * *}$ \\
\hline$\overline{\mathrm{AIC}}$ & 493 & 0.3318 & 0.5283 \\
\hline Observations & 1356 & 952 & 1094 \\
\hline
\end{tabular}

These regressions (Tables 2-5) show that real GDP growth, real interest rates and real GDP per capita are consistently and significantly associated with crisis. These results are consistent with the DD05 findings. However in our case, adding many of the financial variables makes little difference to the model (the coefficients are not significant) and actually reduce the AIC. This is in contrast to DD05 who found that increased budget deficits and private credit/ GDP raised banking crisis probability. 
In regression 3, we find inflation may have a weak negative effect on banking crisis which may reflect procyclical behaviour of asset prices, since during booms, crises are less likely. The fact that higher real GDP growth is consistently found to reduce banking crisis probability confirms it is a robust leading indicator of banking crisis. Apart from directly reducing non-performing loans (and concurrently credit risk), GDP growth may also delay banking crises, again due to procylicality. The coefficients on real interest rates are positive and apart from one regression, significant. This suggests interest rate risk materialisation and financial liberalisation could trigger crises. However the effect of interest rates is not robust to the banking crisis dummy used; alongside the Caprio and Klingebiel (2003) (CK03) dummy, interest rates become insignificant. One explanation may the less stringent crisis criteria CK03 use to classify systemic episodes in comparison to DD05. The DD05 crises are more likely to be fully systemic implying that real interest rates may become a more important trigger if financial instability is endemic as opposed to more localised insolvency. Lagged real credit growth is negatively significant in one specification and insignificant in others whereas DD05 found this variable to be significant albeit in one model specification only. Similarly they found domestic credit/ GDP to be positively associated with crisis, but this variable was not significant in any of our initial regressions.

In contrast to DD05, we find that positive terms of trade shocks consistently reduce banking crisis probability. This may be due to the higher number of small open economies in our sample compared to DD05. Apart from the direct effects on increased loan repayments, favourable terms of trade are also likely to reduce chances of currency crisis. As Kaminsky and Reinhart (1999) show, once a banking crisis is underway, the onset of a currency crisis is likely to deepen banking difficulties.

The Wald test statistics show the coefficients are all significantly different from zero. On the basis of the AIC it appears the most parsimonious model (regression 1) is the best specification of the four regressions. However the changing signs on the coefficients and the insignificance of many variables which DD05 found to be significant indicate the specification may be improved.

\subsection{Improving the Model: Transforming Variables}


Following the first set of regressions, we experimented with data transformations and lags to accommodate the dynamics of banking crises. Furthermore, the occurrence of a banking crisis leaves the economy vulnerable to further crises and may explain the successive crisis episodes observed in many economies. Omitting observations following crisis onset as in DD05 removes this vulnerability from the data. Hence we repeat the regressions retaining all observations.

DD05 do not mention heterogeneity of series but inspection of the data shows significant differences in the magnitude of variables within countries (i.e. between growth and level variables) and between countries. Accordingly, we standardise each series and log several variables (other series have been checked for stationarity). The standardising process involves dividing the deviation of each observation from the pooled mean by the pooled standard deviation, $X_{i, t}{ }^{*}=\left(X_{i, t}-\bar{X}\right) / \sqrt{\operatorname{var}(X)}$, where $X_{i, t}$ is the observation for country i at time $\mathrm{t}, \bar{X}$ is the pooled mean and $\sqrt{\operatorname{var}(X)}$ is the pooled standard deviation. We remove depreciation since it is correlated with terms of trade and it was insignificant in the DD05 regressions. Also we assess for lags in a number of variables, the chosen lags were found from a grid search. Note in particular that credit growth and deposit insurance take quite long lags prior to the crisis, as is plausible (i.e. a crisis may be several years after the credit boom's peak, while deposit insurance takes time to affect risk-taking behaviour).

Tables 6 shows that more indicators now appear as significant predictors of crisis and more leading indicators appear robust to the banking dummy specification. Note however that the lags chosen have also reduced the number of observations compared with Table 5.

Standardising the variables and taking logs where necessary improves significance on many variables. This suggests that without a fixed effects model, unless data is restricted to a homogenous country set, some form of adjustment may be necessary to accommodate variation in the data. This allows a wider cross-country sample to underpin the EWS. We first discuss the overall significance of the explanatory variables following their transformation before explaining why we have selected the lags we have and discussing their significance in the context of banking crisis dynamics in section 3.3.

Real GDP growth remains robustly significantly inversely related to crisis, whichever banking crisis definition used. High real interest rates now appear to significantly increase the probability of banking crisis in accordance with DD05. Moreover, the size of the coefficient 
implies the interest rate risk effect is much stronger in our model. A rise in inflation substantially increases the chances of crises. Unlike DD05, who did not find this variable to be significant, we find the inflation coefficient to be the largest of all. A healthy fiscal surplus seems to signal authorities' general ability to manage policy in a positive sense and their ability to intervene in the banking system if necessary, which reduces crisis likelihood. The significance of this variable increases under our specification compared to DD05. Conversely, the positive coefficient on M2/ Reserves shows an increase in un-backed money adds to the chances of capital flight and thus to the probability of a pure banking or twin crisis. This coefficient was insignificant in our previous specifications.

Table 6: Regression 5: All Variables: Standardisation, More Lags and Logs Introduced

\begin{tabular}{|c|c|c|}
\hline & $\begin{array}{c}\text { D\&D (2005) crisis } \\
\text { dummy }\end{array}$ & $\begin{array}{c}\text { C\&K (2003) crisis } \\
\text { dummy }\end{array}$ \\
\hline & $\begin{array}{c}(1979-2003) \\
105 \text { countries, } 46 \text { crisis } \\
\text { observations (all years) }\end{array}$ & $\begin{array}{c}(1979-2003) \\
105 \text { countries, } \\
81 \text { crisis observations } \\
\text { (all crisis years) }\end{array}$ \\
\hline Log (Real GDP Growth(-2)) & $\begin{array}{l}-0.4026^{* * *} \\
(0.1443)\end{array}$ & $\begin{array}{l}-0.2978^{* * * *} \\
(0.1214)\end{array}$ \\
\hline Change in Terms of Trade & $\begin{array}{c}0.0001 \\
(0.0036)\end{array}$ & $\begin{array}{c}0.0007 \\
(0.0026)\end{array}$ \\
\hline Real Interest Rate (-2) & $\begin{array}{l}0.5729^{*} \\
(0.3499)\end{array}$ & $\begin{array}{l}-0.0354 \\
(0.2851)\end{array}$ \\
\hline Inflation & $\begin{array}{l}17.1924^{* * *} \\
(4.5638)\end{array}$ & $\begin{array}{c}3.4592 \\
(3.8379)\end{array}$ \\
\hline Change in Real GDP per Capita & $\begin{array}{c}-16.6447^{* * *} \\
(6.9907)\end{array}$ & $\begin{array}{c}-16.5295^{* * *} \\
(5.2466)\end{array}$ \\
\hline Fiscal Balance/ GDP & $\begin{array}{l}-0.1711^{* * * *} \\
(0.0525)\end{array}$ & $\begin{array}{c}-0.1238^{* * *} \\
(0.0417)\end{array}$ \\
\hline M2/ International Reserves & $\begin{array}{l}2.7189^{* *} \\
(1.3164)\end{array}$ & $\begin{array}{c}1.9731 \\
(1.3653)\end{array}$ \\
\hline Log (Private Credit/ GDP) & $\begin{array}{l}-0.4394^{* * *} \\
(0.1208)\end{array}$ & $\begin{array}{l}-0.3802^{* * * *} \\
(0.1007)\end{array}$ \\
\hline Credit Growth $(-5)$ & $\begin{array}{l}4.2305^{* *} \\
(2.0514)\end{array}$ & $\begin{array}{l}-0.1574 \\
(0.2362) \\
\end{array}$ \\
\hline Deposit Insurance (-10) & $\begin{array}{l}0.5755^{*} \\
(0.3555)\end{array}$ & $\begin{array}{c}0.1412 \\
(0.2700)\end{array}$ \\
\hline Wald Test Statistic & $113.27^{* * *}$ & $97.03^{* * *}$ \\
\hline $\mathrm{AIC}$ & 0.6417 & 0.9564 \\
\hline Observations & 368 & 368 \\
\hline
\end{tabular}

The negative sign on the private credit/ GDP coefficient indicates that crises are more likely in lesser-developed economies where bank intermediation is the main mechanism of raising 
capital and regulation may be of lower quality. The coefficient on credit growth supports the theory that accumulations in credit risk are a cause of banking crises. The safety net of deposit insurance significantly raises the likelihood of morally hazardous lending by banks, which adds to the crisis probability. Again, this effect appears to be much stronger under our specification compared to DD05. The coefficient on the change in GDP per capita is strongly negative and significant, indicating that improvements in institutional quality associated with higher GDP reduce banking crisis risk.

Whilst the above results seem entirely consistent with banking crisis theory, they are not entirely robust to the choice of baking crisis dummy. Nevertheless, some variables which were insignificant alongside the CK03 definitions when untransformed data was used (regressions 1-4) now appear significant under both dummy definitions: fiscal balance/ GDP and private credit/ GDP. The significance of real GDP per capita now increases for the CK03 dummy in comparison to when data is not standardised. On the other hand, when the CK03 definitions of crisis are used, inflation and credit growth are less significant.

Under the new specification with lags introduced, terms of trade loses significance for both crisis definitions. This may imply that terms of trade shocks play little part in the accumulation of systemic risk, but that (as regression 1-4 show), once risk is amassed systemically, a sudden deterioration in an economy's terms of trade could precipitate a banking crisis.

\subsection{Improving the Model Further: Investigating Dynamics.}

To model the dynamics of banking crises, we now introduce further lags and several interaction variables so that we use the data to mimic the procyclical build up of risk. Our banking crisis story unfolds as follows: credit booms are more likely to occur in an environment which allows imprudent lending, such as following the adoption of deposit insurance. Hence, after deposit insurance is introduced we expect to see rises in domestic credit growth being associated with imprudent lending. This may be tempered if agents are not so reliant on bank intermediation for funds when deposit insurance is installed. To test the impact of credit growth in the presence of deposit insurance, we interact credit growth and deposit insurance at different lags. The results in table 7 clearly show the procyclical behaviour of credit growth. During the boom phase up to four years prior to crisis, credit growth appears to generate credit risk. From three years prior to crisis, a cyclical downturn 
seems to occur with the coefficient sign switching so that credit rationing increases the likelihood of crisis. The fact that the interaction terms are significant (with credit growth alone insignificant) also demonstrates how moral hazard is more prevalent when deposit insurance exists so that credit booms generate considerable banking crisis risk.

Table 7: Regression 6: Procyclicality and Moral Hazard

\begin{tabular}{|c|c|c|}
\hline & $\begin{array}{c}\text { D\&D (2005) crisis } \\
\text { dummy }\end{array}$ & $\begin{array}{c}\text { C\&K (2003) crisis } \\
\text { dummy }\end{array}$ \\
\hline & $\begin{array}{c}(1979-2003) \\
105 \text { countries, } \\
\text { 70crisis observations } \\
\text { (all years) }\end{array}$ & $\begin{array}{c}(1979-2003) \\
105 \text { countries, } \\
100 \text { crisis observations } \\
\text { (all years) }\end{array}$ \\
\hline Log (Real GDP Growth) & $\begin{array}{l}-0.1152 \\
(0.1204) \\
\end{array}$ & $\begin{array}{l}-0.1329 \\
(0.1083)\end{array}$ \\
\hline Change in Terms of Trade & $\begin{array}{c}0.0013 \\
(0.0031)\end{array}$ & $\begin{array}{c}0.0009 \\
(0.0027)\end{array}$ \\
\hline Real Interest Rate & $\begin{array}{c}0.0030 \\
(0.3013)\end{array}$ & $\begin{array}{c}0.0506 \\
(0.2821)\end{array}$ \\
\hline Inflation & $\begin{array}{l}5.6593^{* *} \\
(2.7485)\end{array}$ & $\begin{array}{l}-1.6839 \\
(2.9102)\end{array}$ \\
\hline Change in Real GDP per Capita & $\begin{array}{c}-18.6873^{* * *} \\
(6.9503) \\
\end{array}$ & $\begin{array}{c}-18.7623^{* * *} \\
(5.9710)\end{array}$ \\
\hline Fiscal Balance/ GDP & $\begin{array}{l}-0.0466 \\
(0.0361)\end{array}$ & $\begin{array}{c}-0.0843^{* * * *} \\
(0.0334) \\
\end{array}$ \\
\hline M2/ International Reserves & $\begin{array}{l}12.5815^{* * * *} \\
(4.7478)\end{array}$ & $\begin{array}{l}5.4025^{* *} \\
(2.7862)\end{array}$ \\
\hline Log (Private Credit/ GDP) & $\begin{array}{l}-0.2319^{* *} \\
(0.1037)\end{array}$ & $\begin{array}{l}-0.3905^{* * * *} \\
(0.0941)\end{array}$ \\
\hline Credit Growth*Insurance & $\begin{array}{l}-6.2798^{*} \\
(3.5159)\end{array}$ & $\begin{array}{l}-8.3398^{* *} \\
(3.6856)\end{array}$ \\
\hline Credit Growth*Insurance(-1) & $\begin{array}{c}-10.9812^{* * * 3} \\
(4.2393) \\
\end{array}$ & $\begin{array}{c}-9.2458^{* * * *} \\
(3.7538)\end{array}$ \\
\hline Credit Growth*Insurance $(-2)$ & $\begin{array}{l}-8.1842^{* *} \\
(4.1300) \\
\end{array}$ & $\begin{array}{l}-8.5824^{* *} \\
(3.7562) \\
\end{array}$ \\
\hline Credit Growth*Insurance $(-3)$ & $\begin{array}{l}-2.7540 \\
(2.8714) \\
\end{array}$ & $\begin{array}{c}0.7778 \\
(3.0085) \\
\end{array}$ \\
\hline Credit Growth*Insurance(-4) & $\begin{array}{l}6.4430^{* *} \\
(3.1518)\end{array}$ & $\begin{array}{c}4.6280 \\
(3.0500) \\
\end{array}$ \\
\hline Credit Growth*Insurance(-5) & $\begin{array}{l}7.9458^{* * * *} \\
(3.1063) \\
\end{array}$ & $\begin{array}{l}4.7191^{*} \\
(2.8103) \\
\end{array}$ \\
\hline Credit Growth(-1) & $\begin{array}{l}-1.3292 \\
(2.5000)\end{array}$ & $\begin{array}{c}2.4400 \\
(2.3468)\end{array}$ \\
\hline Credit Growth(-2) & $\begin{array}{c}2.3022 \\
(2.7396) \\
\end{array}$ & $\begin{array}{l}4.9375^{*} \\
(2.6044)\end{array}$ \\
\hline Credit Growth(-3) & $\begin{array}{c}0.1518 \\
(1.4265)\end{array}$ & $\begin{array}{c}-1.9288 \\
(1.6528)\end{array}$ \\
\hline Credit Growth(-4) & $\begin{array}{c}-0.0899 \\
(0.2471)\end{array}$ & $\begin{array}{c}-0.3865 \\
(0.3933) \\
\end{array}$ \\
\hline Credit Growth(-5) & $\begin{array}{l}-0.0729 \\
(0.1235) \\
\end{array}$ & $\begin{array}{l}-0.0251^{*} \\
(0.0846)\end{array}$ \\
\hline $\mathrm{AIC}$ & 0.7089 & 0.8722 \\
\hline Wald Statistic & $156.07^{* * *}$ & $1.35^{* * *}$ \\
\hline Observations & 484 & 484 \\
\hline
\end{tabular}




\subsection{In Sample Predictive Ability}

We now turn to see the relative performances of the different specifications in terms of their ability to accurately call crises and non-crises episodes. It should be noted that the higher the probability threshold set for calling a crisis, the higher the probability of Type I errors (failure to call crisis) and the lower the probability of Type II errors (false alarm). In this regard, we initially set our threshold much higher than Demirguc-Kunt and Detragiache (1998) who set their cut off probability at $0.05^{\frac{19}{19}}$. In contrast we set our threshold at 0.5 , arguing that from the policy maker's perspective, costly intervention on the basis of a crude EWS should be avoided unless the model seriously calls a crisis (table 8a). However the threshold can be changed according to a policy maker's loss function; those that observe a higher historic crisis frequency or who wish to avoid "potential" crisis at all costs can lower the cut off probability. Accordingly we re-estimate in sample predictions using a cut-off probability of 0.05 identical to Demirguc-Kunt and Detragiache (1998). When we reduce our threshold to the DemirgucKunt and Detragiache (1998) level, our models, notably regressions 5 and 6 have dramatically higher crisis predictive ability (table $8 \mathrm{~b}$ ).

Table 8a: In Sample Predictive Ability: Cut-Off Probability = 0.5

\begin{tabular}{|c|c|c|c|c|c|c|c|c|c|}
\hline Regression & \multicolumn{3}{|c|}{1} & \multicolumn{3}{|c|}{2} & \multicolumn{3}{|c|}{3} \\
\hline Probability & \multirow{2}{*}{ DD05* } & \multicolumn{2}{|c|}{ Our Version } & \multirow{2}{*}{ DD05* } & \multicolumn{2}{|c|}{ Our Version } & \multirow{2}{*}{ DD05* } & \multicolumn{2}{|c|}{ Our Version } \\
\hline cut-off $=0.5$ & & DD05 & CK03 & & DD05 & CK03 & & DD05 & CK03 \\
\hline $\begin{array}{c}\% \\
\text { crises correct }\end{array}$ & 60 & 7 & 13 & 60 & 8 & 15 & 58 & 10 & 9 \\
\hline $\begin{array}{c}\% \\
\text { no crises } \\
\text { correct }\end{array}$ & 67 & 96 & 92 & 70 & 96 & 92 & 70 & 96 & 94 \\
\hline $\begin{array}{c}\% \\
\text { total correct }\end{array}$ & 67 & 93 & 87 & 70 & 93 & 87 & 70 & 92 & 89 \\
\hline Regression & \multicolumn{3}{|c|}{4} & \multicolumn{3}{|c|}{5} & & \multicolumn{2}{|c|}{6} \\
\hline \multirow{2}{*}{$\begin{array}{l}\text { Probability } \\
\text { cut-off }=0.5\end{array}$} & \multirow{2}{*}{ DD05* } & \multicolumn{2}{|c|}{ Our Version } & \multirow{2}{*}{ DD05* } & \multicolumn{2}{|c|}{ Our Version } & \multirow{2}{*}{ DD05* } & \multicolumn{2}{|c|}{ Our Version } \\
\hline & & DD05 & CK03 & & DD05 & CK03 & & DD05 & CK05 \\
\hline $\begin{array}{c}\% \\
\text { crises correct }\end{array}$ & 62 & 10 & 5 & NA & 31 & 34 & NA & 34 & 28 \\
\hline $\begin{array}{c}\% \frac{1}{c} \\
\text { no crises } \\
\text { correct } \\
\end{array}$ & 68 & 96 & 95 & NA & 90 & 80 & NA & 98 & 96 \\
\hline $\begin{array}{c}\% \\
\text { total correct }\end{array}$ & 68 & 92 & 89 & NA & 82 & 70 & NA & 89 & 82 \\
\hline
\end{tabular}

* For DD05 cut-off probability is 0.05

\footnotetext{
${ }^{19}$ They decide this threshold on the basis of the frequency of crisis episodes in their sample.
} 
Table 8b: In Sample Predictive Ability: Cut-Off Probability = 0.05

\begin{tabular}{|c|c|c|c|c|c|c|c|c|c|}
\hline Regression & \multicolumn{3}{|c|}{1} & \multicolumn{3}{|c|}{2} & \multicolumn{3}{|c|}{3} \\
\hline \multirow{2}{*}{$\begin{array}{c}\text { Probability } \\
\text { cut-off }=0.05\end{array}$} & \multirow{2}{*}{ DD05 } & \multicolumn{2}{|c|}{ Our Version } & \multirow{2}{*}{ DD05 } & \multicolumn{2}{|c|}{ Our Version } & \multirow{2}{*}{ DD05 } & \multicolumn{2}{|c|}{ Our Version } \\
\hline & & DD05 & CK03 & & DD05 & CK03 & & DD05 & CK03 \\
\hline $\begin{array}{c}\% \\
\text { crises correct }\end{array}$ & 60 & 53 & 66 & 60 & 54 & 66 & 58 & 66 & 66 \\
\hline $\begin{array}{c}\% \\
\text { no crises } \\
\text { correct }\end{array}$ & 67 & 78 & 50 & 70 & 78 & 34 & 70 & 76 & 48 \\
\hline $\begin{array}{c}\% \\
\text { total correct }\end{array}$ & 67 & 77 & 51 & 70 & 78 & 50 & 70 & 75 & 49 \\
\hline Regression & \multicolumn{3}{|c|}{4} & \multicolumn{3}{|c|}{5} & & \multicolumn{2}{|c|}{$\begin{array}{r}1 \\
6 \\
\end{array}$} \\
\hline Probability & & \multicolumn{2}{|c|}{ Our Version } & & \multicolumn{2}{|c|}{ Our Version } & \multirow{2}{*}{ DD05 } & \multicolumn{2}{|c|}{ Our Version } \\
\hline cut-off $=0.05$ & DD05 & DD05 & CK03 & DD05 & DD05 & CK03 & & DD05 & CK05 \\
\hline $\begin{array}{c}\% \\
\text { crises correct }\end{array}$ & 62 & 66 & 66 & NA & 91 & 99 & NA & 91 & 99 \\
\hline $\begin{array}{c}\% \\
\text { no crises } \\
\text { correct }\end{array}$ & 68 & 77 & 45 & NA & 44 & 12 & NA & 32 & 23 \\
\hline $\begin{array}{c}\% \\
\text { total correct }\end{array}$ & 68 & 76 & 50 & NA & 50 & 31 & NA & 40 & 39 \\
\hline
\end{tabular}

Table 8 (a) shows that with a cut-off probability of 0.5 , our models are better at calling noncrisis periods correctly although the ability to call crisis episodes is substantially lower than DD05. This is as we would expect given the trade-off between Type I and Type II errors and the higher cut-off. However once we lower the threshold to the same level as DD05 at 0.05, our models out-perform the DD05 models in terms of crisis prediction (apart from regressions 1 and 2). This is independent of the crisis dummy used. Moreover, a dynamic model such as Model 5 is notably better at predicting crisis events with above $90 \%$ of crisis episodes being called correctly.

Both tables also show that given the same threshold, the CK03 crisis dummy generally is better predicted by these variables that the DD05 dummy. This may be due to the wider definitions of crisis that $\mathrm{CK} 03$ use so that the CK03 dummy is associated with a reduced ability to call non-crisis periods correctly and therefore a higher chance of Type II errors. Table $8 \mathrm{~b}$ shows our models do not appear to lose much in terms of Type II errors when the cut-off probability is lowered to 0.05 since based on the DD05 dummy, our $\%$ of non-crisis events correctly predicted is marginally higher than the DD05 models. As a result, our models consistently outperform the DD05 models in term of total correct predictions but only if the DD05 dummy is used. If the CK03 dummy is used, our models underperform in total; again this is probably due to the wider crisis definitions of the CK03 dummy which results in reduced ability to identify non-crisis periods. 
Overall these results that incorporating dynamics substantially improves crisis predictive ability with no significant cost in terms of false alarms. It also illustrates the tradeoff of Type I and Type II errors in logit models.

\subsection{Banking crisis prediction using the method of Kaminsky and Reinhart (1999)}

Using exactly the same dataset as the previous logit regressions, we now conduct a signal extraction approach in the manner of Kaminsky and Reinhart (1999), henceforth KR9920. The KR99 methodology locates the optimal threshold using a common percentile for the crosscountry distribution of each variable. Whilst we will adopt this approach, we also argue that minimisation of a common percentile may be problematic. If the $20^{\text {th }}$ percentile is chosen as the optimal threshold across all cross-sections, this is equivalent to the notion that whenever real GDP growth falls into the lowest $20 \%$ of observations in any country, a crisis is imminent. Whilst for some countries during some time periods this may be reasonably correct, for other countries it may not; certain countries may undergo structural changes (e.g. financial liberalisation, move from recession to boom) which generate different distributions for the indicator and their optimal threshold may differ accordingly. Hence generalisation to a common percentile threshold may limit the predictive ability of panel based EWS. Accordingly we test whether country specific and general grid searches give rise to different optimal thresholds. We then compare the in-sample predictive ability of the two approaches.

To optimise thresholds on the basis of country specific data we compute the NTSR for each country using a selection of percentiles. We use a forecasting horizon of two years - one year prior to the crisis and the crisis year itself. Our horizon is considerably more stringent than the KR99 signalling window which consists of 54 months (18 months before the crisis, an 18 month crisis episode and 18 months after the crisis). We choose a shorter signalling window because where there are multiple crisis episodes, signalling windows may overlap. Also, because we use annual data, our signalling window is restricted to yearly increments. The lowest NTSR given by the threshold corresponding to each country is then aggregated into a common threshold. Table 9 and Graphs 1-8 show our optimal thresholds (in terms of percentiles) and the corresponding correct predictions, where "General" refers to the common percentile approach used by KR99.

\footnotetext{
${ }^{20}$ We therefore abandon the KR99 variable list which is more focused on detecting balance of payments difficulties.
} 


\section{Graph 1: REAL GDP GROWTH}

COUNTRY SPECIFIC THRESHOLD

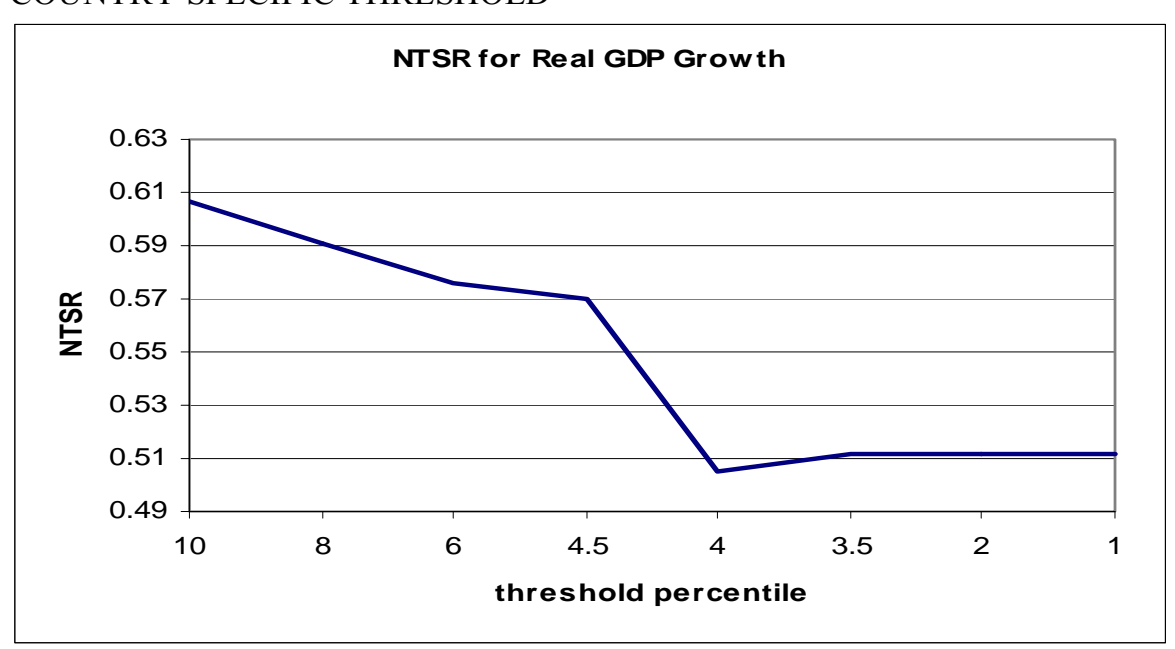

\section{Graph 2: TERMS OF TRADE}

COUNTRY SPECIFIC THRESHOLD

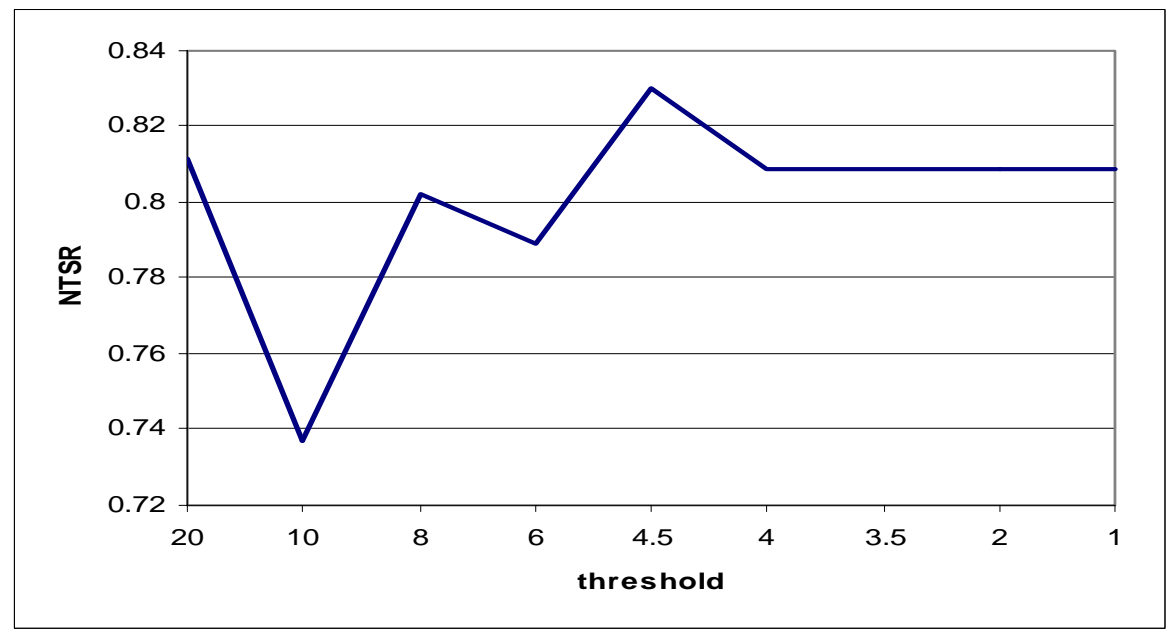

GENERAL THRESHOLD

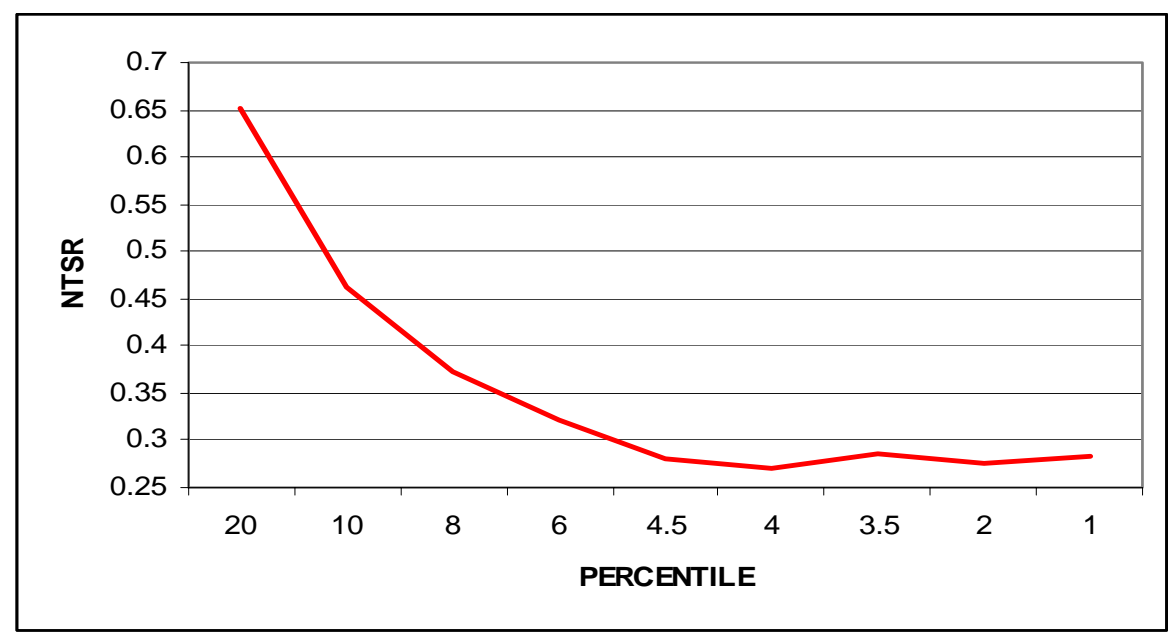

GENERAL THRESHOLD

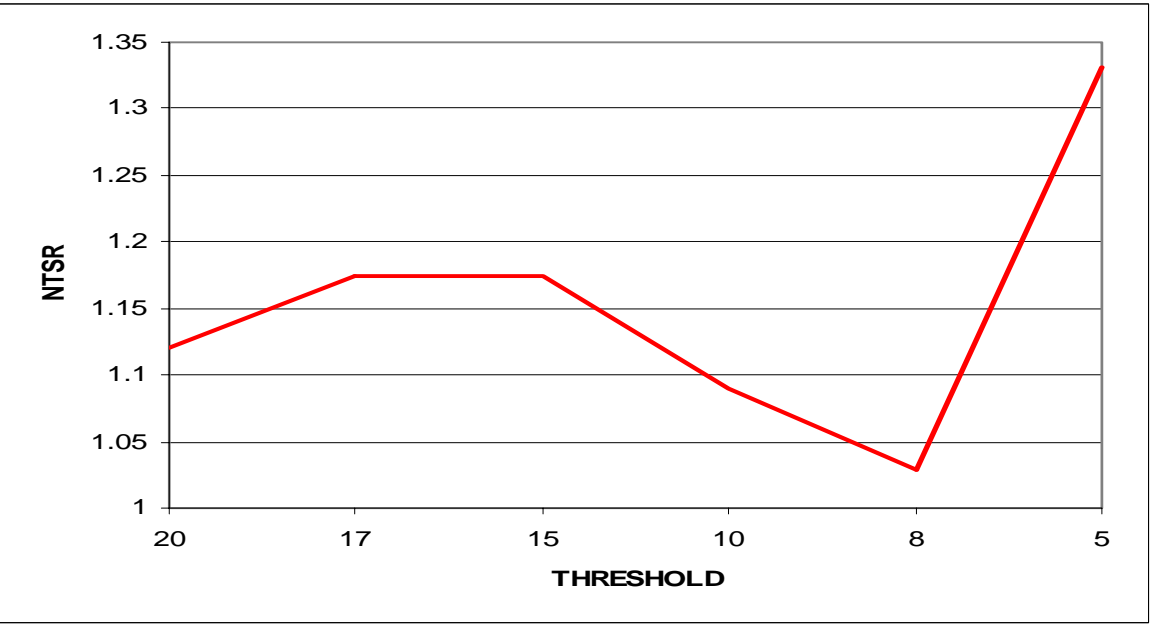




\section{Graph 3: REAL INTEREST RATE}

COUNTRY SPECIFIC THRESHOLD

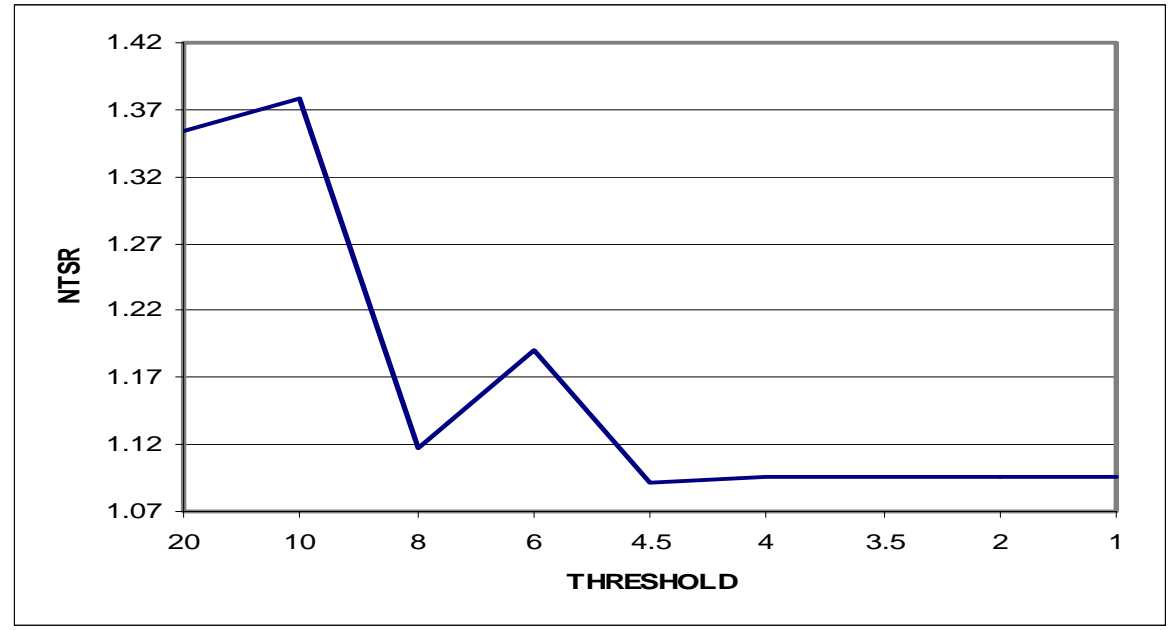

\section{Graph 4: DEPRECIATION}

COUNTRY SPECIFIC THRESHOLD

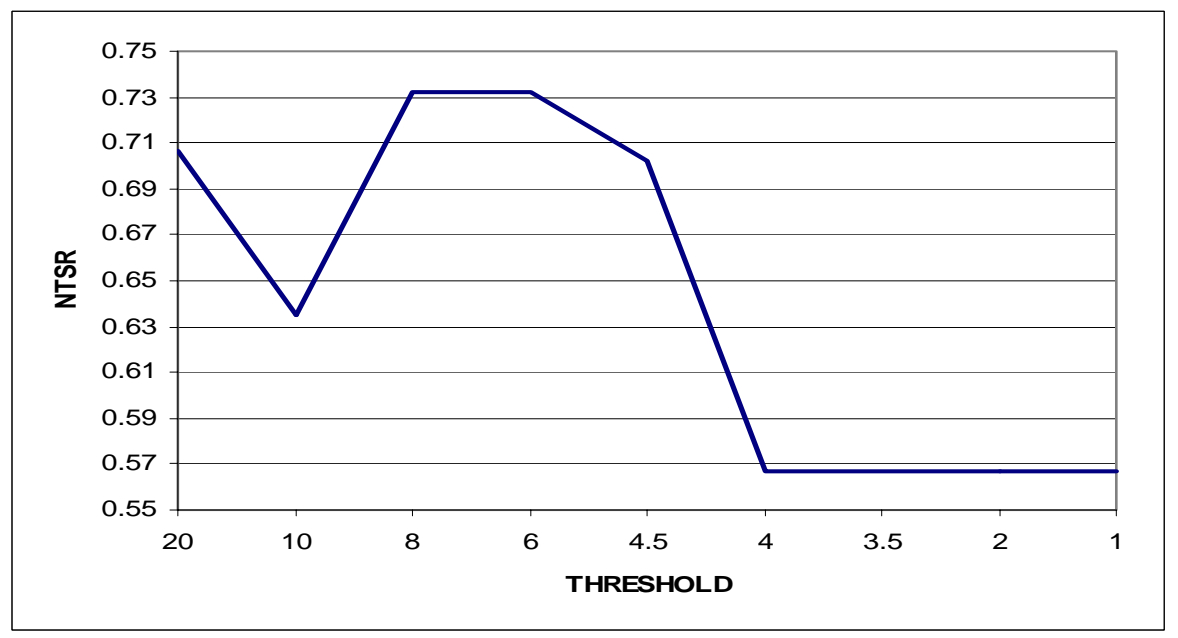

GENERAL THRESHOLD

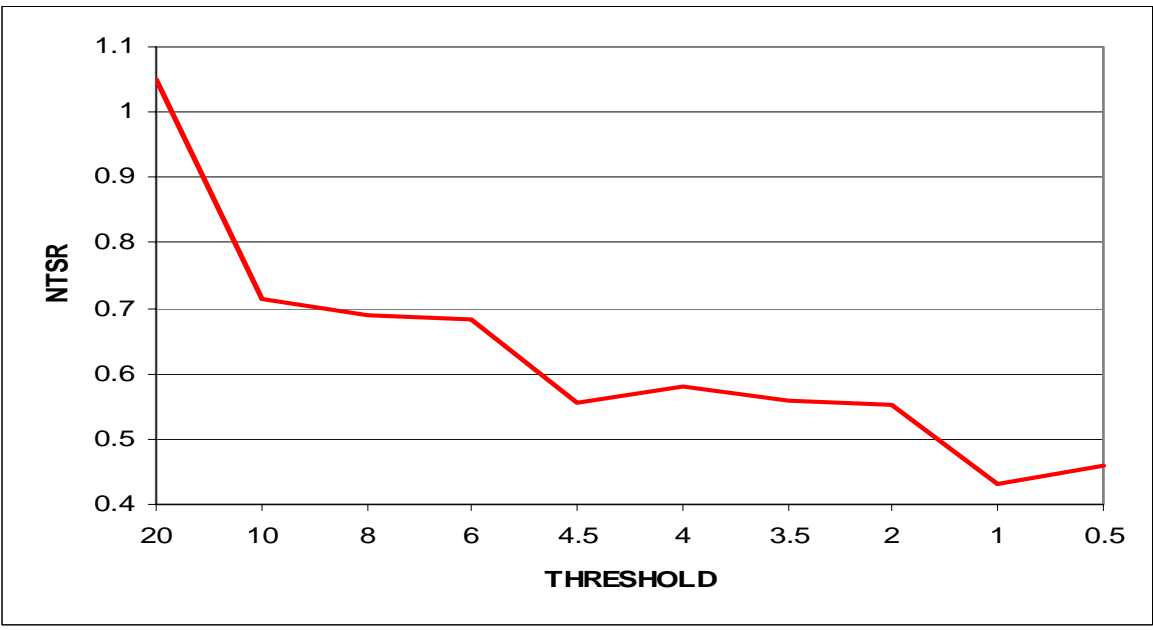

GENERAL THRESHOLD

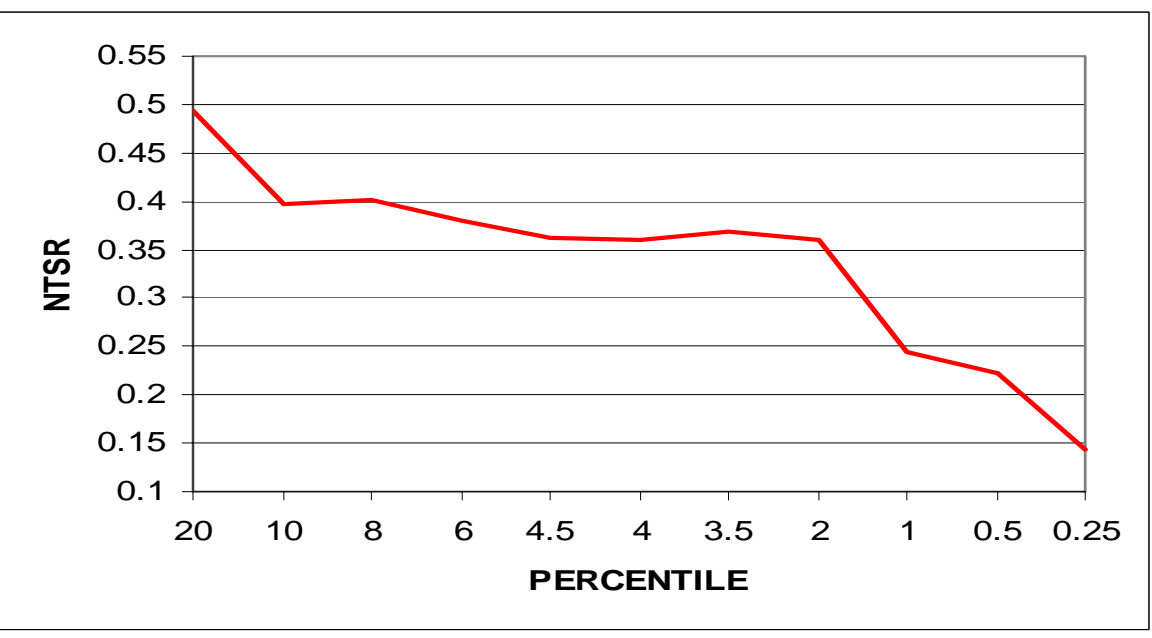




\section{Graph 5: INFLATION}

COUTNRY SPECIFIC THRESHOLD

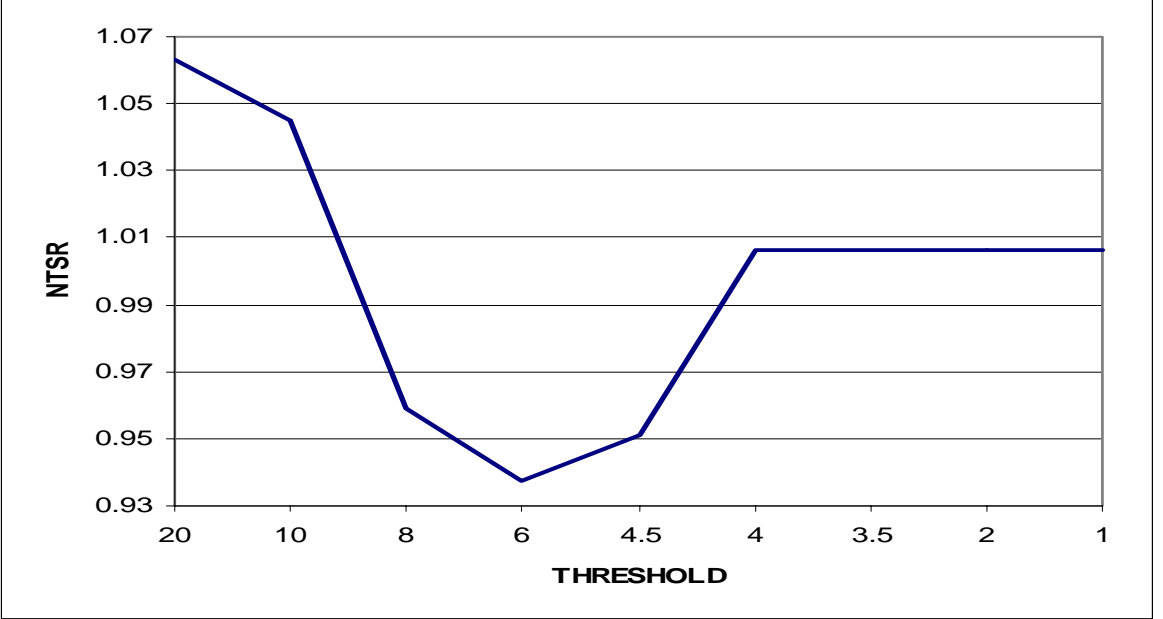

\section{Graph 6: BUDGET BALANCE}

COUNTRY SPECIFIC THRESHOLD

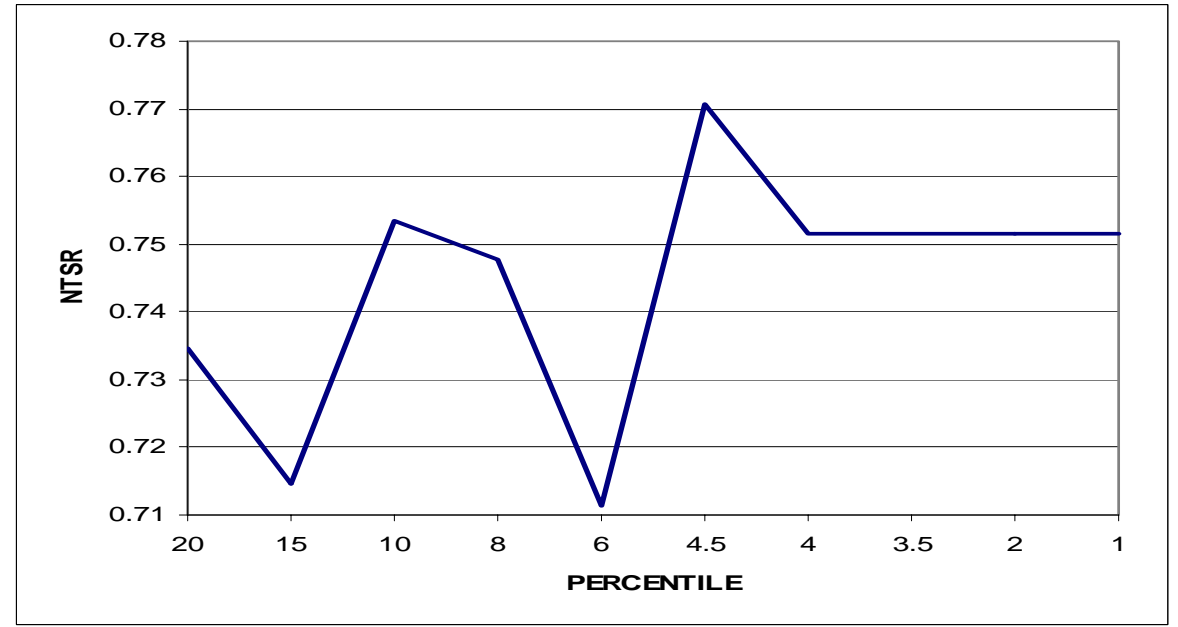

GENERAL THRESHOLD
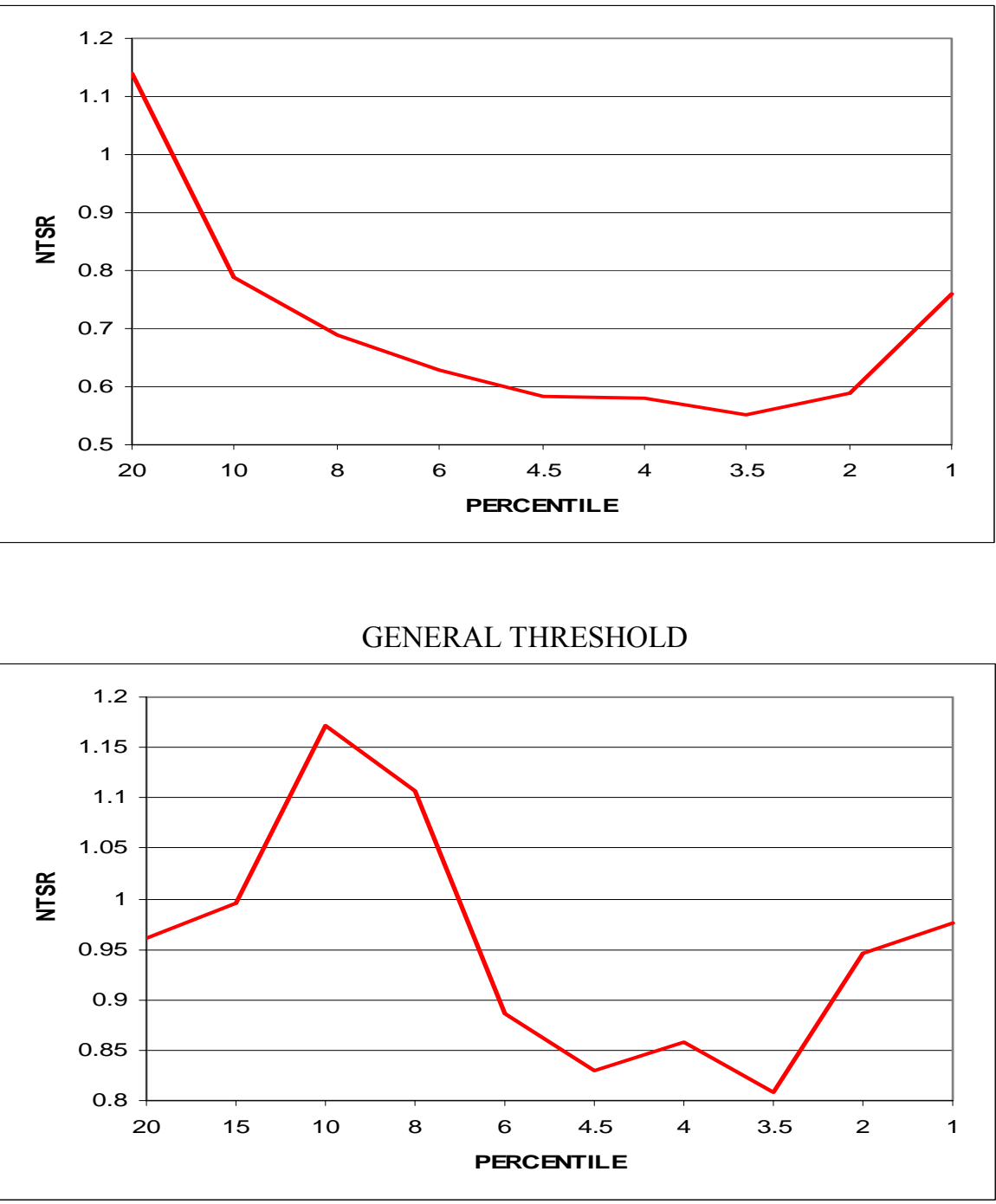


\section{Graph 7: M2 / RESERVES}

COUNTYR SPECIFIC THRESHOLD

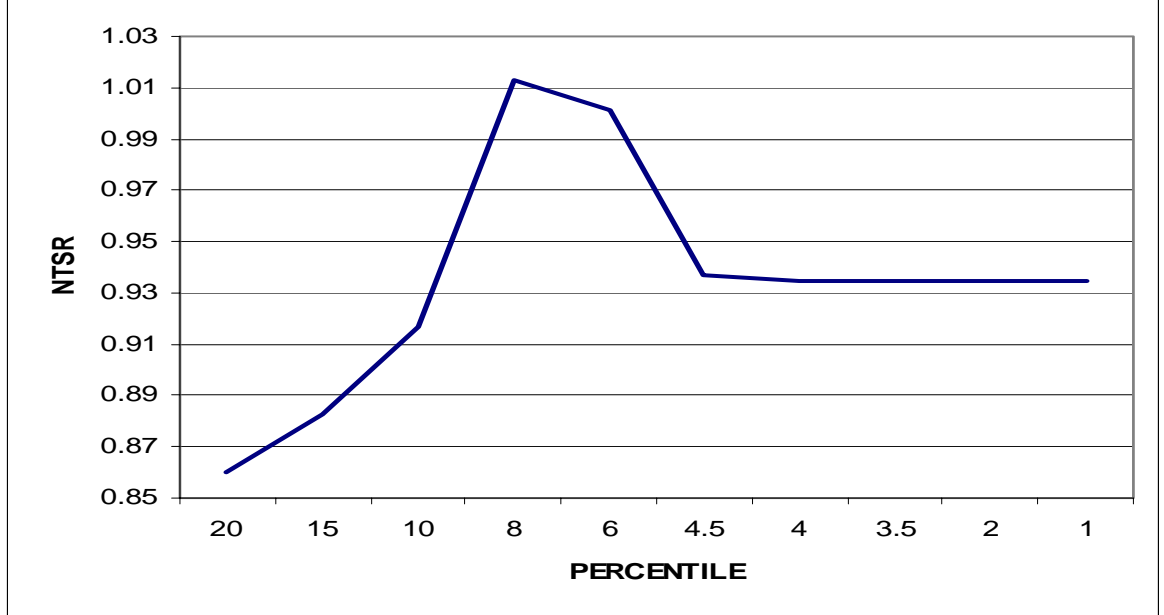

Graph 8: CREDIT / GDP RATIO

COUNTRY SPECIFIC THRESHOLD

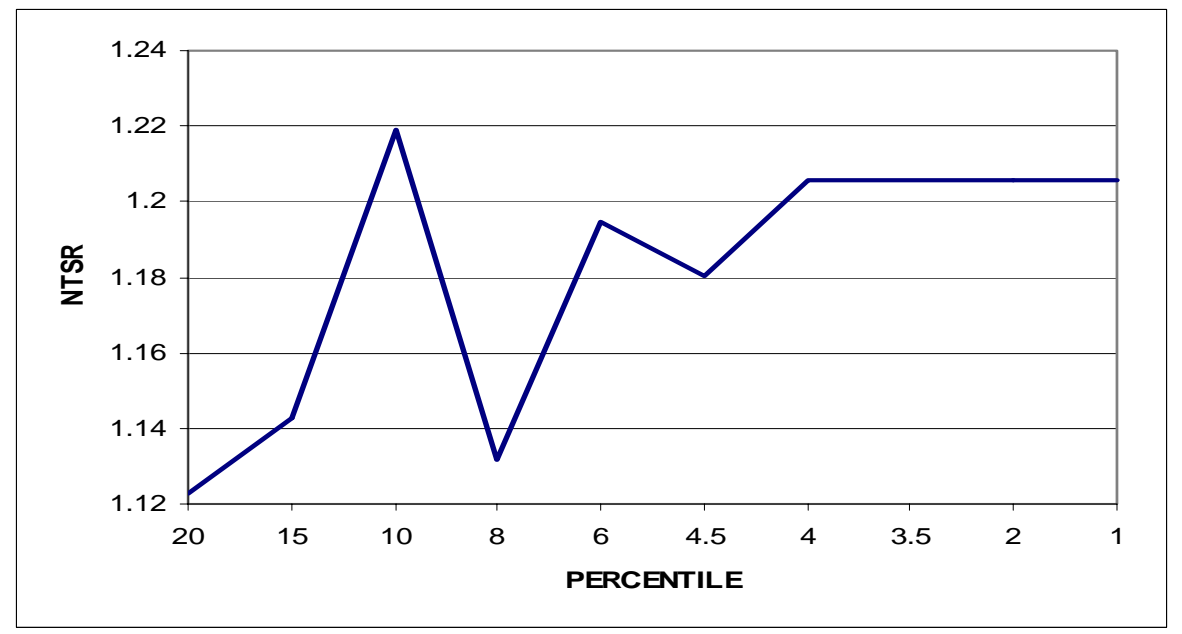

GENERAL THRESHOLD

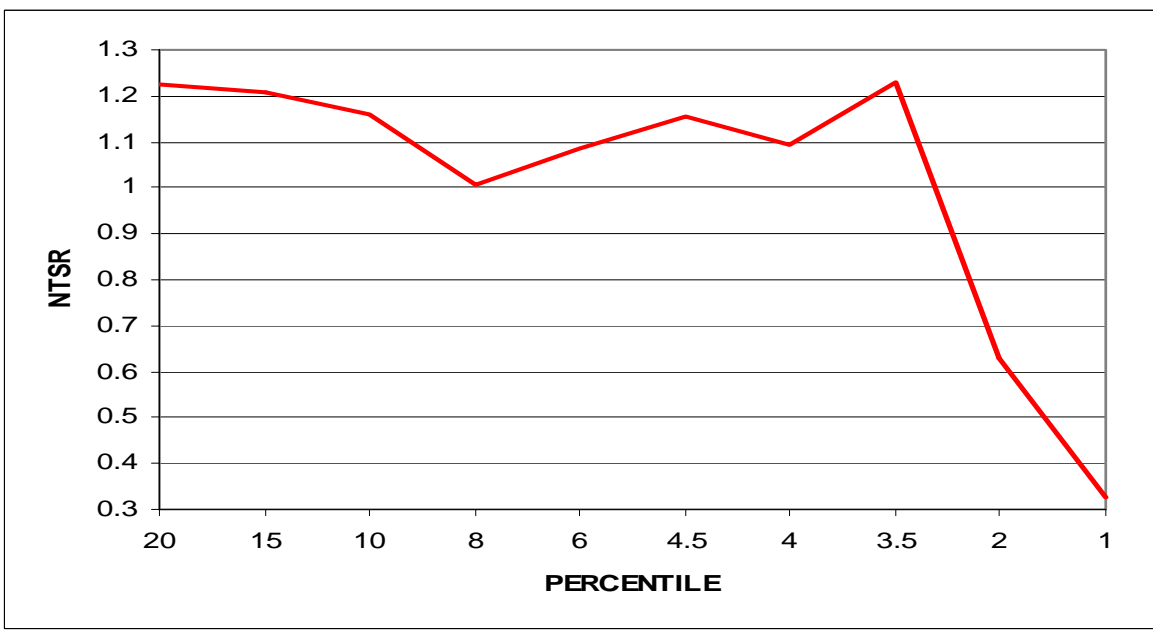

GENERAL THRESHOLD

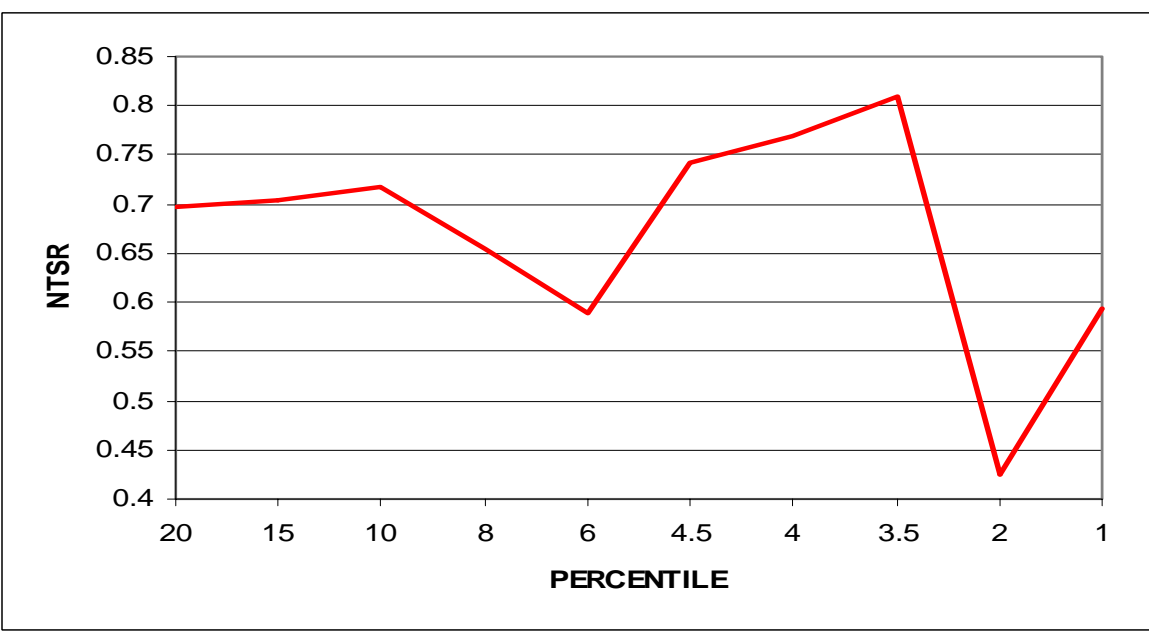


Table 9: Comparison of In-Sample Predictive Ability for General and Country Specific Thresholds.

\begin{tabular}{|c|c|c|c|c|}
\hline & \multicolumn{2}{|c|}{ Real GDP Growth } & \multicolumn{2}{|c|}{ Terms of Trade } \\
\hline & Country Specific & General & Country Specific & General \\
\hline Optimal Percentile & 8 & 4 & 10 & 8 \\
\hline NTSR & 0.5904 & 0.2701 & 0.7370 & 1.0284 \\
\hline$\%$ crisis correct & 12 & 10 & 15 & 7 \\
\hline$\%$ no crisis correct & 93 & 97 & 89 & 93 \\
\hline \multirow[t]{3}{*}{$\%$ total correct } & 81 & 84 & 76 & 78 \\
\hline & \multicolumn{2}{|c|}{ Real Interest Rate } & \multicolumn{2}{|c|}{ Depreciation } \\
\hline & Country Specific & General & Country Specific & General \\
\hline Optimal Percentile & 4.5 & 1 & 4 & 2.5 \\
\hline NTSR & 1.0917 & 0.4309 & 0.5667 & 0.1436 \\
\hline$\%$ crisis correct & 7 & 2 & 6 & 1 \\
\hline$\%$ no crisis correct & 92 & 99 & 96 & 100 \\
\hline \multirow[t]{3}{*}{$\%$ total correct } & 80 & 85 & 82 & 84 \\
\hline & \multicolumn{2}{|c|}{ Inflation } & \multicolumn{2}{|c|}{ Budget Surplus } \\
\hline & Country Specific & General & Country Specific & General \\
\hline Optimal Percentile & 6 & 4 & 6 & 4 \\
\hline NTSR & 0.9373 & 0.5509 & 0.7113 & 0.8084 \\
\hline$\%$ crisis correct & 9 & 6 & 12 & 4 \\
\hline$\%$ no crisis correct & 92 & 97 & 91 & 97 \\
\hline \multirow[t]{3}{*}{$\%$ total correct } & 79 & 83 & 79 & 82 \\
\hline & \multicolumn{2}{|c|}{ M2/ Reserves } & \multicolumn{2}{|c|}{ Credit/ GDP } \\
\hline & Country Specific & General & Country Specific & General \\
\hline Optimal Percentile & 20 & 1 & 8 & 2 \\
\hline NTSR & 0.8598 & 0.3246 & 1.1318 & 0.4251 \\
\hline$\%$ crisis correct & 23 & 2 & 8 & 4 \\
\hline$\%$ no crisis correct & 80 & 99 & 91 & 98 \\
\hline$\%$ total correct & 71 & 84 & 78 & 83 \\
\hline
\end{tabular}

The results show there is a big difference between country specific and general thresholds and that as a result, the optimal percentile differs widely. Using a country specific optimisation procedure results in a higher percentage of crises being predicted compared to the generalised threshold method. However, the general threshold procedure is better at calling non-crisis episodes, so that there are a higher chance of Type I errors with the general method and conversely, a higher chance of Type II errors with the specific method. Given that there is a high ratio of non-crisis to crisis observations in the sample, overall the general procedure performs better in terms of total correct predictions. As a result, the general threshold virtually always gives a lower NTSR to the specific threshold where values below one indicate the variables are informative.

In terms of individual leading indicator performance, the best predictors of crisis appear to be real GDP growth and changes in the terms of trade. This is consistent with the panel logit 
results. M2/ reserves and budget surpluses are also better than other indicators at calling crises.

Although we follow the Kaminsky and Reinhart (1999) procedure, we are unable to compare most of our indicator performances with theirs since they conducted their estimations for a different sample of countries and different time frames, using mostly different indicators on a monthly basis 21 . However comparison of indicators common to our study and theirs (real interest rates and domestic credit/ GDP) shows our indicators are considerably worse at calling banking crises correctly compared to theirs. For Kaminsky and Reinhart (1999), real interest rates are able to call $100 \%$ of crises correctly whilst domestic credit/ GDP is able to call $50 \%$ of crises correctly. However the authors do not mention their indicators' ability to call non-crisis periods correctly or the level of Type II errors that arise with such high prediction rates.

Overall our results suggest there may be policy implications for the selection of the optimisation procedure. Policy makers who place emphasis on crisis avoidance may utilise the country specific approach. However the results also imply that a country specific signal extraction model, where thresholds are derived from historic data for a single country is more likely to incorporate more information when selecting the optimal threshold. Much of this heterogeneity is averaged away when deriving global thresholds. We next turn to investigate whether combining indicators changes the trade off between Type I and Type II indicators for our dataset.

\subsection{Furthering the Signal Extraction Approach: Composite Indicators}

Borio and Lowe (2002) developed the Kaminsky and Reinhart (1999) procedure by constructing composite indicators 22 to extract signals of banking crisis. Their approach is to select indicators which a priori are thought to contain information for banking crisis prediction. They then aggregate these variables to generate a composite signal whereby the indicator is switched on if all constituent variables cross their respective thresholds simultaneously. Selection of optimal composite thresholds is achieved by a grid search to

\footnotetext{
${ }^{21}$ Kaminsky and Reinhart (1999) base their study on 20 small open economies with a fixed exchange rate or a crawling peg over a period 1970-1995. Their sample contained 26 banking crises, 19 of which were twinned. Because they were investigating balance of payments crises as well as twin crises, the variables they used were predominantly different to ours which are based on the DD05 study.

${ }^{22}$ They actually focus on the accumulation of risk by integrating different variables' departures from trend into one composite variable.
} 
identify the minimum NTSR. However, the noteworthy difference to the KR99 approach is that the Borio and Lowe (2002) method implicitly gives more weight to Type II errors, since they consider the failure to predict crises outweighs the costs of unnecessary intervention. Their more stringent requirement that all individual indicators in the composite must cross their thresholds for the composite to signal, means when a crisis is called it is more likely to happen; the probability of a Type I error is reduced at the cost of higher levels of Type II errors.

In this section we also generate composite indicators but our method differs from Borio and Lowe (2002). We do not impose a requirement that all indicators within the composite must cross their thresholds for the composite to signal. Rather, we construct a composite indicator in the manner of Kaminsky (1999) which may signal crisis even if some of the individual indicators have not crossed their thresholds. Although we do not assign any weights to Type I or II errors, we do construct composites based on the general and specific methodologies followed in section 3.4. Since these two approaches have been shown to favour Type I and Type II errors differently, we wish to see if this behaviour persists when we construct composites. We also investigate whether creating composite indicators affects the informational content of the indicator.

Kaminsky (1999) constructs the composite (C) by weighting each component variable by the inverse of its noise to signal ratio (equation 5), where $\mathrm{S}_{\mathrm{j}}^{\mathrm{t}}$ is the signal for variable $\mathrm{j}$ at time $\mathrm{t}$ and $\omega^{\mathrm{j}}$ is the noise to signal ratio for variable $\mathrm{j}$.

$$
\mathrm{C}=\sum_{\mathrm{t}=1}^{\mathrm{T}} \frac{\mathrm{S}_{\mathrm{j}}^{\mathrm{t}}}{\omega^{\mathrm{j}}}
$$

The Kaminsky (1999) criterion for inclusion in the composite is that the variable must generate a noise to signal ratio of less than one since this implies the variable contains a higher proportion of information than noise. In our case, we set stronger criteria; we first construct a composite indicator using variables that have a noise to signal ratio of 0.5 or less and then we construct composites using variables where the ratio is 0.75 or less. Table 10 lists the indicators that qualify for each composite; for the 0.5 cut-off, none of the variables qualify using the country specific approach and we are left with a composite based on the general threshold approach. For the 0.75 cut-off we construct two composites based on the general and country specific approaches. 
Table 10: Variables Qualifying for the Composite Indicator

\begin{tabular}{|c|c|c|}
\hline 0.5 NTSR cut-off & \multicolumn{2}{|c|}{0.75 NTSR cut-off } \\
\hline General & General & Country Specific \\
\hline Real GDP Growth & Real GDP Growth & Real GDP Growth \\
\hline Real Interest Rate & Real Interest Rate & Terms of Trade \\
\hline Depreciation & Depreciation & Depreciation \\
\hline M2/ Reserves & M2/ Reserves & Budget Balance \\
\hline $\begin{array}{c}\text { Domestic Credit/ } \\
\text { GDP }\end{array}$ & $\begin{array}{c}\text { Domestic Credit/ } \\
\text { GDP }\end{array}$ \\
\hline & Inflation & \\
\hline
\end{tabular}

Table 11 and Graph 9 show the results for the general and specific approaches based on the different cut-offs for the NTSRs. In section 3.4 we showed the trade-off between Type I and II errors when selecting between the general and country specific threshold approach, where the general (specific) approach reduced Type II errors (Type I errors) at the cost of higher Type I (Type II) errors. A comparison of the general and specific methods for the composite indicator based on the NTSR $\leq 0.75$ shows that this trade-off persists even if composite indicators are constructed. Hence the general approach continues to weight Type II errors more heavily whilst the specific approach remains better for policy makers wishing to avoid unnecessary intervention costs.

In terms of percentage of crises correctly called, both composites based on the general approach outperform six of the eight indicators used in section 3.4. On the other hand, the ability to call non-crisis periods correctly is drastically reduced since the general composite underperforms against seven of the eight indicators. Similarly, the composite based on the country specific method outperforms six of the single variables at calling crises but underperforms all except one in its ability to call non-crisis periods correctly.

The composite method therefore appears to improve crisis prediction whether a country specific or general threshold approach is used but this occurs at the cost of higher Type II errors. As a result, the overall percentage observations correctly called deteriorates with both types of composite so that they outperform only one univariate indicator in this respect. The composite approach raises Type II errors across the board and the general approach has a lower chance of Type II errors than the specific approach. Hence, we would expect the composite method to change the NTSR based on the general approach more than it changes the specific approach NTSR. The results confirm this since both the general composites are 
equalised at a NTSR of 0.69 which is higher than virtually all the NTSRs for single indicators based on the same approach.

Conversely, the specific threshold approach which already yields low Type I errors benefits from the composite method so that the composite specific threshold approach lowers the NTSR below that of virtually all the univariate indicators with the same methodology. Graph 9 shows there is a difference in optimal percentile thresholds between the general and country specific approaches at the $4^{\text {th }}$ percentile and the $10^{\text {th }}$ percentile respectively. However using different values for the NTSR (0.5 and 0.75) as a criterion for individual indicator acceptance into the composite makes no difference to the optimal threshold or the optimal NTSR.

To summarise, creating a composite indicator increases the likelihood of correctly calling crises compared to the univariate approach but raises the chances of false alarms. Although the general approach benefits in terms of crisis prediction, it is penalised by the higher level of Type II errors and the NTSR is correspondingly higher than when single variables act as signallers using the same approach. The gains in crisis identification from using a composite approach conform to the findings of Borio and Lowe (2002) although these authors found efficiency increased due to a reduction in Type II errors.

Table 11: Comparison of In Sample Predictive Ability of Composite Indicators Using General and Country Specific Thresholds.

\begin{tabular}{|c|c|c|c|}
\hline & 50 NTSR cut-off & \multicolumn{2}{|c|}{ 75 NTSR cut-off } \\
\hline & General & General & Country Specific \\
\hline Optimal Percentile & 4 & 4 & 10 \\
\hline NTSR & 0.6911 & 0.6911 & 0.5541 \\
\hline \% crisis correct & 7 & 7 & 15 \\
\hline \% crisis correct & 95 & 95 & 88 \\
\hline \% total correct & 82 & 82 & 77 \\
\hline
\end{tabular}




\section{Graph 9: Comparison of Noise to Signal Ratios for Composite Indicators}

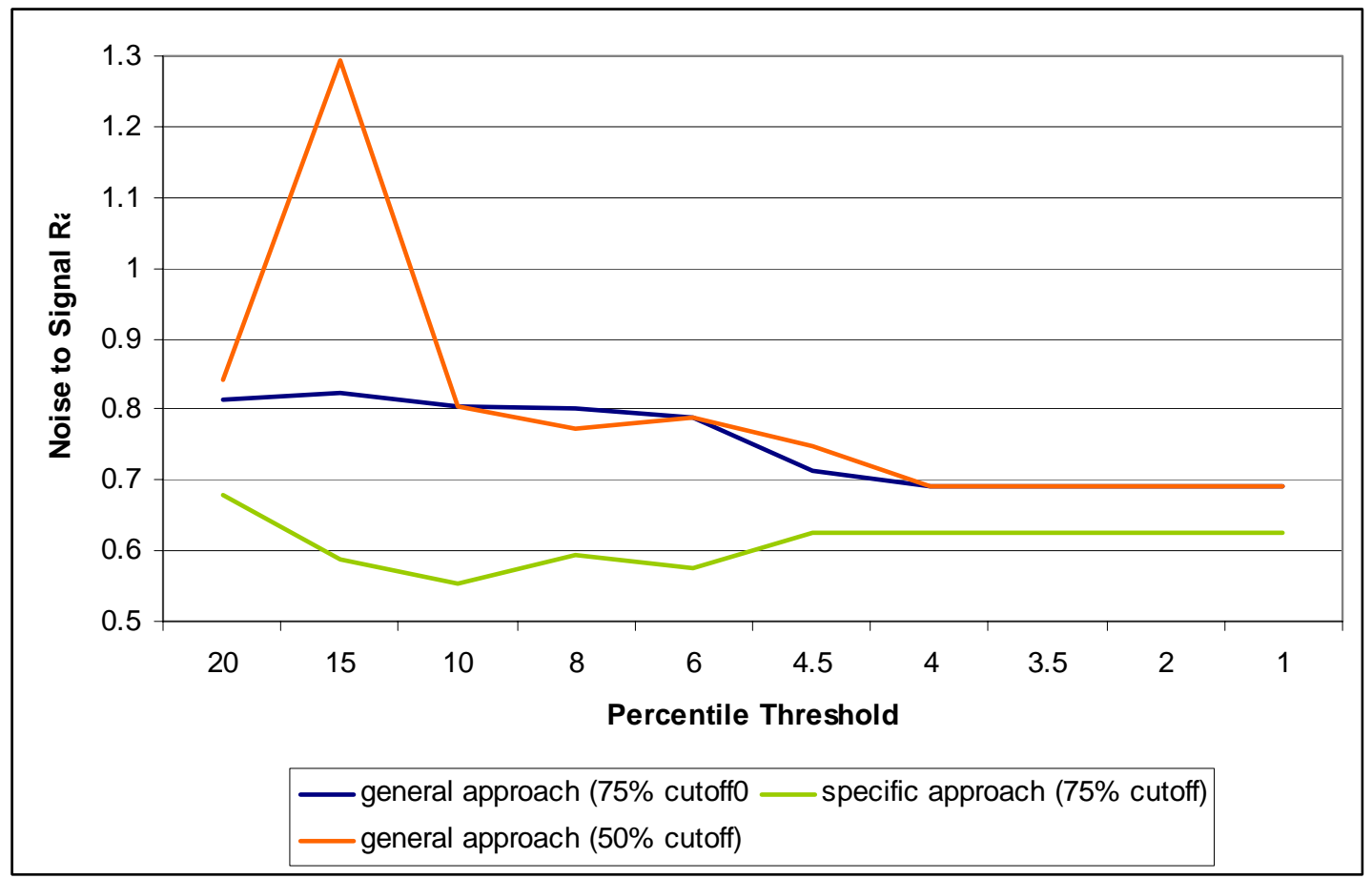

\subsection{Comparison of the Signal Extraction and Multivariate Logit Models.}

On the basis of in-sample predictive ability, the multivariate logit model outperforms the signal extraction approach in terms of the percentage of crises correctly predicted. Even the best leading indicator in the signal extraction approach (M2/ Reserves) is able to call only $23 \%$ of crises correctly, whereas our dynamic multivariate models (regressions 5 and 6) are able to call an average of $32 \%$ of crises, despite us setting our cut-off probability much higher than DD05 and well over $90 \%$ of crises using their 0.05 probability.

Berg and Pattillo (1999) who conducted a comparison of multivariate probit and signal extraction EWS for currency crisis prediction also found the multivariate approach outperformed the univariate method. With the signal extraction approach, every indicator misses a substantial number of crises. Berg and Pattillo (1999) suggest this is because the signal extraction process assumes that a threshold for a variable is a discrete value and that whenever this is crossed, a crisis becomes impending. In actual fact, as graphs 1-8 show, the NTSRs "jump" between thresholds so that there is no smooth relationship between threshold and crisis probability, something that Berg et al (2004) also note. If the NTSR jumps at different threshold for different countries, then using cross-country data to derive a common threshold may not be fruitful; the threshold that minimises the NTSR will fall on either side of the individual optimal thresholds for most countries. In this case, the percentage of crises 
correctly called will be sub-optimal compared to where threshold are analysed for individual countries.

The multivariate logit on the other hand, assumes a specific smooth non-linear form for the relationship between crisis probability and variable behaviour. As the results suggest, this may be closer to the truth of banking crises, especially once dynamics are taken into account and given that a large number of crisis episodes across many countries are being assessed simultaneously for both models.

Even if indicators are aggregated to a composite, the percentages of crises predicted do not match the dynamic multivariate logit models, although percentage crisis prediction improves. An alternative approach to ours would be the Borio and Lowe (2002) methodology where individual variable thresholds are jointly evaluated. In this sense, composite indicator ability to predict crises is more comparable to the multivariate logit model than the univariate signal extraction procedure so the two procedures could be compared on the same dataset. This is a subject of further research for banking crisis prediction.

\section{Conclusion}

A comparison of the multinomial logit and signal extraction procedures shows that real GDP growth and terms of trade are robust leading indicators of banking crisis for our comprehensive sample. Results for other variables are mixed in terms of robustness and as comparison with the DD05 model shows, results vary according to the dataset used and the banking crisis definition adopted. Moreover, given the same dataset we show that the choice of estimation techniques makes a difference in terms of indicator performance and crisis prediction. Where a multinomial logit is used, transformations which take into account crosscountry heterogeneity may improve model specification since the use of logit prevents fixed effects estimation. Where a signal extraction procedure is used, optimising thresholds country by country improves ability to correctly predict crises. Creating composite indicators may further improve crisis prediction. Hence the use of the multinomial logit model may be better suited to a global EWS whereas the signal extraction approach may be better suited to country specific EWS.

We also show that dynamics of banking crises are an extremely important consideration when designing an EWS since procyclical variables may have an independent effect on banking 
crisis and a joint effect with institutional factors. In such cases the sequencing of institutional reforms and procyclical movements in credit and real GDP growth become important. Using contemporaneous data for all variables ignores the build up of financial instability that arises from the procyclical behaviour of many indicators. Once we took theory into account and used the data to incorporate a more realistic story of crisis, indicator significance improved. Despite a much higher probability threshold than the DD05 study, our logit model was able to call a significant proportion of crises correctly.

As noted, international financial institutions do not employ an EWS specifically for banking crisis. However, given the ongoing liberalisation of emerging market financial sectors as well as the changing nature of banking risks as more economies move into market and securitised banking phases, the use of EWS for crisis prevention is more necessary than ever. As we have shown, it is important to consider the policy maker's objectives when designing predictive models since there is a trade of between correctly calling crises and false alarms. In this sense our study confirms that EWS for banking crises are a necessary but not sufficient tool for predicting further crisis episodes, since a generalised global model cannot be a substitute for country-specific macroprudential surveillance.

\section{References:}

Berg, Andrew and Pattillo, Catherine, (1999)."Predicting currency crises: The indicators approach and an alternative," Journal of International Money and Finance, Elsevier, vol. 18(4), pages 561-586, August.

Berg, Andrew, Borensztein, Eduardo and Pattillo, Catherine, (2004). “Assessing Early Warning Systems: How Have They Worked In Practice?” IMF Working Paper, WP/04/52, International Monetary Fund, Washington.

Borio, Claudio, Craig Furfine, and Philip Lowe (2001) 'Procyclicality of the financial system and financial stability: issues and policy options,' BIS Papers No. 1, BIS.

Borio, Claudio and Lowe, Philip (2002). “Assessing the Risk of Banking Crisis”, BIS Quarterly Review, December 2002.

Caprio, Gerard and Klingebiel, Daniela, (July 1996). "Bank Insolvencies: Cross-Country Experience". World Bank Policy Research Working Paper No. 1620.

Caprio, Gerard and Daniela Klingebiel, (2003). "Episodes of Systemic and Borderline Financial Crises.” World Bank Research Dataset.

Chan, Getmansky, Haas and Lo (2006). "Systemic Risk and Hedge Funds", in "The Risks of Financial Institutions", (p. 235-330), University of Chicago Press.

Chari, V V and Jagannathan, Ravi, (1988) " Banking Panics, Information, and Rational Expectations Equilibrium," Journal of Finance, American Finance Association, vol. 43(3), pages 749-61, July.

Craig R S, Davis E P and Garcia A (2005), "Sources of procyclicality in East Asian financial systems", in eds S Gerlach and P Gruenwald, "Procyclicality of financial systems in Asia", Palgrave McMillan 
Das, Udaibir, Quintyn, Marc, G, and Chenard, Kina (2004). "Does Regulatory Governance Matter for Financial System Stability? An Empirical Analysis “. IMF Working Paper No. 04/89, International Monetary Fund, Washington.

Davis, E Phillip (1995). “Debt, Financial Fragility and Systemic Risk”. Oxford University Press.

Davis E P (1999), "Russia/LTCM and market liquidity risk", The Financial Regulator, 4/2, Summer 1999, 23-28

Davis E P and Zhu H (2004), "Bank lending and commercial property prices, some cross country evidence", BIS Working Paper No 150

Davis E P and Zhu H (2005), "Commercial property prices and bank performance", BIS Working Paper No 175

Demirguc-Kunt, A. and Detragiache, E. (1998). "The Determinants of Banking Crises in Developed and Developing Countries”. IMF Staff Paper, Vol. 45, No. 1, International Monetary Fund, Washington.

Demirguc-Kunt, Asli \& Detragiache, Enrica, (2002). "Does deposit insurance increase banking system stability? An empirical investigation," Journal of Monetary Economics, Elsevier, vol. 49(7), pages 1373-1406, October.

Demirgüç-Kunt, Asli and Detragiache, Enrica (2005). "Cross-Country Empirical Studies of Systemic Bank Distress: A Survey." IMF Working Papers 05/96, International Monetary Fund.

Diamond D. and Dybvig P. (1983). "Bank runs, deposit insurance and liquidity”. Journal of Political Economy, 91, 401-19.

Eichengreen, B. and Arteta C. (2000). "Banking Crises in Emerging Markets: Presumptions and Evidence". Centre for International Development and Economics Research Working Paper, C00-115, August.

Eichengreen, Barry and Rose, Andrew K. (1998). "Staying Afloat When the Wind Shifts: External Factors and Emerging-Market Banking Crises," NBER Working Papers 6370, National Bureau of Economic Research, Inc.

Ergungor, E and Thompson, James (2005). "Systemic Banking Crises", Policy Discussion Papers, Federal Reserve Bank of Cleveland, Number 9, February 2005.

Federal Deposit Insurance Corporation (1997). "Commercial Real Estate and the Banking Crises of the 1980s and Early 1990s". In "An Examination of the Crises of the 1980s and Early 1990s", Volume 1, Chapter 3, FDIC.

George, E. A. J. (1998). "The New Lady of Threadneedle Street". Governor's Speech, Bank of England, London, February 24.

Glick, Reuven and Hutchison, Michael (1999). "Banking and currency crises; how common are twins?," Proceedings, Federal Reserve Bank of San Francisco, issue Sep.

Gonzalez-Hermosillo, Brenda (1999). "Developing Indicators to Provide Early Warnings of Banking Crises". Finance and Development, Volume 36, Number 2, IMF Publications, Washington.

Gorton, G. (1988). “Banking Panics and Business Cycles”. Oxford Economic Papers, Vol. 40, pp 751-781.

Gourinchas, Pierre-Olivier, Valdes, Rodrigo and Landerretche, Oscar, (2001). "Lending Booms: Latin America and the World." NBER Working Papers 8249, National Bureau of Economic Research, Inc.

Greene, W. H. (2000). “Econometric Analysis.” Prentice Hall International, Co., London, UK .

Hardy, Daniel C. L. and Pazarbasioglu, Ceyla (1998). "Leading Indicators of Banking Crises-Was Asia Different?," IMF Working Papers 98/91, International Monetary Fund.

Herring, Richard J. and Wachter, Susan M. (1998). "Real Estate Cycles and Banking Crises: An International Perspective". Zell/Lurie Center Working Papers 298, Wharton School Samuel Zell and Robert Lurie Real Estate Center, University of Pennsylvania.

Hoggarth, Glen and Saporta, Victoria (2001). "Costs of Banking System Instability: Some Empirical Evidence." June, Financial Stability Review. 
Honohan, Patrick, (2000). "How Interest Rates Changed under Financial Liberalization: A Cross-Country Review ". World Bank Policy Research Working Paper No. 2313.

Jacklin, C. and Bhattacharya, S. (1988). "Distinguishing Panics and Information-Based Bank Runs: Welfare and Policy Implications". Journal of Political Economy, vol. 96(3), pages 568-92, June, University of Chicago Press.

Kaminsky, Graciela (1999). “"Currency and Banking Crises: The Early Warnings of Distress". IMF Working Paper No. 99/178.

Kaminsky L.G. and Reinhart C.M. (1999). "The twin crises; the causes of banking and balance of payments problems". The American Economic Review, Vol. 89, No. 3, pp 473-500.

Kaufman, George, G. and Scott, Kennneth, E. (2003). "What is Systemic Risk and Do Bank Regulators Retard or Contribute to It?" The Independent Review, Volume 7, Number 3, Winter 2003.

Lindgren Carl-Johan, Garcia, Gillian and Saal, Matthew, (Eds.) (1996). "Bank Soundness and Macroeconomic Policy”. International Monetary Fund, Washington.

Mckinnon, Ronald, I. (1973). "Money and Capital in Economic Development." Washington, Brookings Institution.

Naude, Willem (1996). "Financial liberalisation and interest rate risk management in Sub-Saharan Africa", Working Paper, Centre for the Study of African Economies, Oxford, WPS/96.12.

Oviedo, Pedro Marcelo (2004). "Macroeconomic risk and banking crises in emerging market countries: business fluctuations with financial crashes," Proceedings, Federal Reserve Bank of San Francisco, issue Jun.

Santos, Joao (2000). "Bank Capital Regulation in Contemporary banking Theory: A Review of the Literature". BIS Working Papers, No. 90, September 2000, Bank of International Settlements.

Stiglitz, Joseph (1994). "The Role of the State in Financial Markets", in Bruno and Peskovic eds. Proceedings of the World Bank Annual Conference on Development Economics, Washington, World Bank. 
APPENDIX:

Country List

\begin{tabular}{|c|c|c|}
\hline Algeria & India & Switzerland \\
\hline Antigua/Barbuda & Indonesia & Syria \\
\hline Argentina & Ireland & Tanzania \\
\hline Australia & Israel & Thailand \\
\hline Austria & Italy & Togo \\
\hline Bahamas & Jamaica & Trinidad and Tobago \\
\hline Bahrain & Japan & Tunisia \\
\hline Bangladesh & Jordan & Turkey \\
\hline Barbados & Kenya & Uganda \\
\hline Belgium & Korea & UK \\
\hline Bolivia & Laos & Ukraine \\
\hline Botswana & Lebanon & Uruguay \\
\hline Brazil & Madagascar & USA \\
\hline Burundi & Malaysia & Venezuela \\
\hline Cameroon & Mali & Vietnam \\
\hline Canada & Mauritius & Zambia \\
\hline Chile & Mexico & Zimbabwe \\
\hline Colombia & Mozambique & \\
\hline Congo & Myanmar & \\
\hline Costa Rica & Nepal & \\
\hline Cyprus & Netherlands & \\
\hline Czech Republic & New Zealand & \\
\hline Denmark & Nicaragua & \\
\hline Dominica & Niger & \\
\hline Dominican republic & Nigeria & \\
\hline Ecuador & Norway & \\
\hline Egypt & Panama & \\
\hline El Salvador & Papua New Guinea & \\
\hline Equatorial Guinea & Paraguay & \\
\hline Ethiopia & Peru & \\
\hline Finland & Philippines & \\
\hline France & Poland & \\
\hline Germany & Portugal & \\
\hline Ghana & Romania & \\
\hline Greece & Russia & \\
\hline Grenada & Senegal & \\
\hline Guatemala & Seychelles & \\
\hline Guinea Bissau & Sierra Leone & \\
\hline Guyana & Singapore & \\
\hline Haiti & South Africa & \\
\hline Honduras & Spain & \\
\hline Hong Kong & Sri Lanka & \\
\hline Hungary & Swaziland & \\
\hline Iceland & Sweden & \\
\hline
\end{tabular}

